\title{
Long-term trends in aerosol and precipitation composition over the western North Atlantic Ocean at Bermuda
}

\author{
W. C. Keene ${ }^{1}$, J. L. Moody ${ }^{1}$, J. N. Galloway ${ }^{1}$, J. M. Prospero ${ }^{2}$, O. R. Cooper $^{3,4}$, S. Eckhardt ${ }^{5}$, and J. R. Maben ${ }^{1}$ \\ ${ }^{1}$ Department of Environmental Sciences, Clark Hall, University of Virginia, Charlottesville, VA, 22904-4123, USA \\ ${ }^{2}$ Division of Marine and Atmospheric Chemistry, University of Miami, 4600 Rickenbacker Causeway, Miami, FL, \\ 33149-1098, USA \\ ${ }^{3}$ Cooperative Institute for Research in Environmental Sciences (CIRES), University of Colorado, Boulder, CO, 80305, USA \\ ${ }^{4}$ NOAA Earth Systems Research Laboratory, Boulder, CO, 80305, USA \\ ${ }^{5}$ Norwegian Institute for Air Research, Kjeller, Norway
}

Correspondence to: W. C. Keene (wck@virginia.edu)

Received: 17 February 2014 - Published in Atmos. Chem. Phys. Discuss.: 14 March 2014

Revised: 30 May 2014 - Accepted: 4 June 2014 - Published: 13 August 2014

\begin{abstract}
Since the 1980s, emissions of $\mathrm{SO}_{2}$ and $\mathrm{NO}_{\mathrm{x}}$ $\left(\mathrm{NO}+\mathrm{NO}_{2}\right)$ from anthropogenic sources in the United States (US), Canada, and Europe have decreased significantly suggesting that the export of oxidized $\mathrm{S}$ and $\mathrm{N}$ compounds from surrounding continents to the atmosphere overlying the North Atlantic Ocean (NAO) has also decreased. The chemical compositions of aerosols and precipitation sampled daily on Bermuda $\left(32.27^{\circ} \mathrm{N}, 64.87^{\circ} \mathrm{W}\right)$ from 1989 to 1997 and from 2006 to 2009 were evaluated to quantify the magnitudes, significance, and implications of associated tends in atmospheric composition. The chemical data were stratified based on FLEXPART (FLEXible PARTicle dispersion model) retroplumes into four discrete transport regimes: westerly flow from eastern North America (NEUS/SEUS); easterly trade-wind flow from northern Africa and the subtropical NAO (Africa); long, open-ocean, anticyclonic flow around the Bermuda High (Oceanic); and transitional flow from the relatively clean open ocean to the polluted eastern North America (North). Based on all data, annual average concentrations of non-sea-salt (nss) $\mathrm{SO}_{4}^{2-}$ associated with aerosols and annual volume-weighted-average (VWA) concentrations in precipitation decreased significantly (by $22 \%$ and $49 \%$, respectively) whereas annual VWA concentrations of $\mathrm{NH}_{4}^{+}$in precipitation increased significantly (by $70 \%$ ). Corresponding trends in aerosol and precipitation $\mathrm{NO}_{3}^{-}$and of aerosol $\mathrm{NH}_{4}^{+}$were insignificant. $\mathrm{Nss}^{2-} \mathrm{SO}_{4}^{2-}$ in precipitation under NEUS/SEUS and Oceanic flow decreased significantly (61\% each) whereas corresponding trends in particulate nss
\end{abstract}

$\mathrm{SO}_{4}^{2-}$ under both flow regimes were insignificant. Trends in precipitation composition were driven in part by decreasing emissions of $\mathrm{SO}_{2}$ over upwind continents and associated decreases in anthropogenic contributions to nss $\mathrm{SO}_{4}^{2-}$ concentrations. Under NEUS/SEUS and Oceanic flow, the ratio of anthropogenic to biogenic contributions to nss $\mathrm{SO}_{4}^{2-}$ in the column scavenged by precipitation were relatively greater than those in near surface aerosol, which implies that, for these flow regimes, precipitation is a better indicator of overall anthropogenic impacts on the lower troposphere. Particulate nss $\mathrm{SO}_{4}^{2-}$ under African flow also decreased significantly $(34 \%)$ whereas the corresponding decrease in nss $\mathrm{SO}_{4}^{2-}$ associated with precipitation was insignificant. We infer that these trends were driven in part by reductions in the emissions and transport of oxidized S compounds from Europe. The lack of significant trends in $\mathrm{NO}_{3}^{-}$associated with aerosols and precipitation under NEUS/SEUS flow is notable in light of the large decrease $(37 \%)$ in $\mathrm{NO}_{\mathrm{x}}$ emissions in the US and Canada over the period of record. Rapid chemical processing of oxidized $\mathrm{N}$ in marine air contributed to this lack of correspondence. Decreasing ratios of nss $\mathrm{SO}_{4}^{2-}$ to $\mathrm{NH}_{4}^{+}$and the significant decreasing trend in precipitation acidity $(37 \%)$ indicate that the total amount of acidity in the multiphase gas-aerosol system in the western NAO troposphere decreased over the period of record. Decreasing aerosol acidities would have shifted the phase partitioning of total $\mathrm{NH}_{3}\left(\mathrm{NH}_{3}+\right.$ particulate $\left.\mathrm{NH}_{4}^{+}\right)$towards the gas phase thereby decreasing the atmospheric lifetime of total $\mathrm{NH}_{3}$ 
against wet plus dry deposition. The trend of increasing $\mathrm{NH}_{4}^{+}$ in precipitation at Bermuda over the period of record suggests that $\mathrm{NH}_{3}$ emissions from surrounding continents also

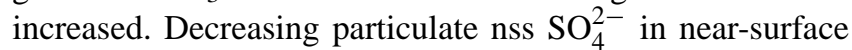
air under NEUS/SEUS flow over the period of record implies that the corresponding shortwave scattering and absorption by nss $\mathrm{S}$ and associated aerosols constituents also decreased. These changes in radiative transfer suggest a corresponding lower limit for net warming over the period in the range of $0.1-0.3 \mathrm{~W} \mathrm{~m}^{-2}$.

\section{Introduction}

It has been recognized for many years that material emitted to the atmosphere from continental sources can be transported long distances over adjacent oceans. For example, reports of crustal aerosol transported from northern Africa over the open North Atlantic Ocean (NAO) have been published in the scientific literature since the late 1700 s (e.g., Dobson, 1781; Darwin, 1846). More recently, trace elements and reaction products from $\mathrm{S}$ and $\mathrm{N}$ species emitted by anthropogenic combustion and industrial sources were detected in atmospheric aerosols and precipitation over the NAO (e.g., Zoller et al., 1973; Jickells et al., 1982; Chen and Duce, 1983). Subsequent, studies have attempted to quantitatively differentiate relative contributions from major source types (continental versus marine; anthropogenic versus biogenic versus crustal) and major source regions based on analysis of elemental and molecular tracers (e.g., Arimoto et al., 1995; Savioe et al., 2002), radionuclides (e.g., Arimoto et al., 1999), isotopic composition (e.g, Turekian et al., 2001, 2003; Hastings et al., 2003; Lin et al., 2012), air-mass transport history (e.g., Moody and Galloway, 1988; Galloway et al., 1989; Moody et al., 1995, 2014), and satellite remote sensing (e.g., Zhao et al., 2008; Zhang and Reid, 2010; Hsu et al., 2012; Prospero et al., 2012). These and other studies indicate that the transport of anthropogenic emissions and reaction products from North America is the dominant source of pollutants associated with aerosols and precipitation over the western NAO at Bermuda. However, anthropogenic emissions from surrounding continents have changed significantly over the past quarter century suggesting that relative impacts of anthropogenic sources to air quality over the western NAO have also changed.

Implementation of the Clean Air Act and associated amendments in the United States (US) and similar legislation in Europe in the late 1980s and early 1990s led to substantial reductions in emissions of $\mathrm{SO}_{2}$ and $\mathrm{NO}_{\mathrm{x}}$ to the atmosphere surrounding the North Atlantic Basin (e.g., Vestreng, 2007; Hand et al., 2012). For example, emission inventories prepared by the US Environmental Protection Agency (EPA, 2013) indicate that, between 1980 and 2012, total emissions of $\mathrm{SO}_{2}$ and $\mathrm{NO}_{\mathrm{x}}$ in the US decreased by $80 \%$ and $50 \%$, respectively. In contrast, reported emissions of $\mathrm{NH}_{3}$ in the US between 1990 (the earliest year available) and 2012 differed by less than $1 \%$ (EPA, 2013). Thus, the relative mixture of acids (from $\mathrm{SO}_{2}$ and $\mathrm{NO}_{\mathrm{x}}$ oxidation) and bases in the planetary boundary layer (PBL) over the US and, presumably, associated $\mathrm{pH}$-dependent chemical processes, also evolved temporally over this period. Reductions in $\mathrm{SO}_{2}$ and $\mathrm{NO}_{\mathrm{x}}$ emissions led to corresponding decreases in annual average $\mathrm{SO}_{2}$ and $\mathrm{NO}_{\mathrm{x}}$ mixing ratios in ambient air over the US during the same period ( $78 \%$ and $56 \%$, respectively) (EPA, 2013). Concentrations of particulate-phase reaction products from the oxidation of $\mathrm{SO}_{2}$ and $\mathrm{NO}_{\mathrm{x}}$ as well as aerosol optical depth (AOD) also decreased and visibility improved. For example, between 2000 (the earliest year available) and 2012, average annual concentrations of $\mathrm{PM}_{2.5}$ mass in near-surface air over the US decreased by $33 \%$ (EPA, 2013), between 2000 and 2010, particulate $\mathrm{SO}_{4}^{2-}$ concentrations in rural areas of the US decreased by $27 \%$ (Hand et al., 2012) and, between 1980 and 2006, simulated AOD over the US decreased by $38 \%$ (Streets et al., 2009). Reductions in emissions have also led to large decreases in the atmospheric deposition of $\mathrm{SO}_{4}^{2-}, \mathrm{NO}_{3}^{-}$and $\mathrm{H}^{+}$and the associated recovery of some degraded watersheds in the eastern US (Kahl et al., 2004; Webb et al., 2004; Leibensperger et al., 2012).

The above trends for the US suggest that the chemical and optical properties of the western NAO atmosphere have also changed significantly over the past quarter century analogous to the sharp decreases in lead over the NAO that followed the phaseout of leaded gasoline in the US (Shen and Boyle, 1987). Although not significant, Zhang and Reid (2010) reported a decreasing trend in AOD over the western NAO between 2000 and 2009. During the same period $\mathrm{SO}_{2}$ and $\mathrm{NO}_{\mathrm{x}}$ emissions in the US decreased by $49 \%$ and $31 \%$, respectively, and simulated AOD over the continental US also decreased (Streets, et al., 2009). Based on satellite observations of AOD and the chemical composition of nearsurface aerosols, Moody et al. (2014) estimate that, under transport from the northeastern US during the period 20062009, pollutant aerosol accounted for direct radiative cooling at Bermuda of $1.0-2.2 \mathrm{~W} \mathrm{~m}^{-2}$. However, potential changes in AOD resulting from emission reductions in the US were not evaluated.

In this paper, we investigate long-term trends in the chemical composition of aerosols and precipitation over the western NAO at Bermuda with a focus on evaluating impacts of emission reductions and influences of different source regions. This work is based on measurements between 1989 and 1997 under the auspices of the Atmosphere Ocean Chemistry Experiment (AEROCE) and comparable measurements between 2006 and 2009 at the same location. 


\section{Methods}

\subsection{Sampling site, periods, and protocols}

From June 1988 to July 1998, aerosols in sectored (onshore) flow at the Tudor Hill Atmospheric Observatory (THAO) on Bermuda $\left(32.27^{\circ} \mathrm{N}, 64.87^{\circ} \mathrm{W}\right)$ were sampled daily for chemical characterization from the top of a $23 \mathrm{~m}$ scaffolding tower situated on a steep slope about $25 \mathrm{~m}$ above sea level. Samples were collected in bulk at a nominal flow rate of $1.0 \mathrm{~m}^{3} \mathrm{~min}^{-1}$ on Whatman 41 filters $(20.3 \times 25.4 \mathrm{~cm})$ as part of AEROCE (Galloway et al., 1993; Savoie et al., 2002). Data were blank corrected based on analysis of paired bulkfilter cassettes deployed periodically in parallel with samples but through which no air was pulled.

From July 2006 to June 2009, dichotomous aerosol (nominal super- and submicrometer-diameter size fractions) was sampled daily at a rate of $0.1 \mathrm{~m}^{3} \mathrm{~min}^{-1}$ with a customdesigned and fabricated MSP model 130 high-flow cascade impactor configured with a Liu-Pui-type omnidirectional inlet (Liu et al., 1983). Relative to MSP's Micro-Orifice Uniform Deposit Impactor (MOUDI) (Marple et al., 1991) that is in more widespread use by the research community, these hiflow impactors yield greater signal per unit deployment time while segregating aerosol size fractions using similar nozzle technology. Impactors were deployed at the top of the THAO tower (Moody et al., 2014). The calculated inlet passing efficiency for $20 \mu \mathrm{m}$ diameter particles was $95 \%$ and the $50 \%$ aerodynamic cut between the two size factions was $0.8 \mu \mathrm{m}$ in ambient diameter. Impactors were configured with quartzfiber (Pallflex 2500 QAT-UP) substrates $(75 \mathrm{~mm}$ diameter) and back filters ( $90 \mathrm{~mm}$ diameter). Dichotomous data were blank-corrected based on analysis of impactor substrates and back filters through which air was briefly pulled $(\sim 15 \mathrm{~s})$. Between 2006 and 2009, a blank impactor was exposed and processed approximately once every 2 weeks.

With the exception of the differences noted above, aerosol sampling and handling procedures prior to analysis during both periods were virtually identical. Sampling was controlled by sensors that activated pumps only during periods of no precipitation when surface winds were off the ocean sector at speeds greater than $1 \mathrm{~m} \mathrm{~s}^{-1}$. Air volumes were measured with sharp-edged flow tubes and normalized to standard temperature and pressure $\left(0^{\circ} \mathrm{C}\right.$ and $\left.1 \mathrm{~atm}\right)$. Bulk cassettes and impactors were cleaned with $18 \mathrm{M} \Omega \mathrm{cm}^{-1}$ deionized water (DIW), and dried, loaded, and unloaded in a class 100 clean bench mounted in a laboratory container at the base of the tower. After recovery, exposed sample and blank filters and substrates were folded in half, sealed in clean polyethylene bags, and stored (and shipped) frozen prior to analysis. Samples and corresponding blanks during each period were processed and analyzed using identical analytical procedures.
From July 1988 to April 1997 and from July 2006 to June 2009 , wet-only precipitation in unsectored air was sampled daily from the top of the THAO tower in precleaned $13.2 \mathrm{~L}$ polyethylene buckets mounted in an automated collector (Galloway et al., 1993). Precipitation amount was measured in parallel with both bulk and recording rain gauges; precipitation amounts reported herein correspond to those measured with the bulk gauge. After recovery, sample aliquots ( $250 \mathrm{~mL}$ or less for low volume events) were transferred to precleaned polyethylene bottles, sterilized on site via addition of $500 \mu \mathrm{L} \mathrm{CHCl}_{3}$ to prevent microbial activity (Keene et al., 1983; Herlihy et al., 1987), and stored refrigerated prior to analysis. During both periods, precipitation was sampled and processed prior to chemical analysis using identical procedures.

\subsection{Sample analysis}

Aerosol sampled from 1988 to 1998 was analyzed at the University of Miami (UM) for $\mathrm{SO}_{4}^{2-}, \mathrm{NO}_{3}^{-}$, and $\mathrm{NH}_{4}^{+}$by suppressed ion chromatography (IC), and for $\mathrm{Na}^{+}$by flame atomic absorption spectroscopy (AA) (Galloway et al., 1993; Savoie et al., 2002). From 1988 to 1996, particulate $\mathrm{CH}_{3} \mathrm{SO}_{3}^{-}$ was also measured at UM by IC. Aerosols sampled from 2006 to 2009 were analyzed at the University of Virginia (UVA) by IC for $\mathrm{CH}_{3} \mathrm{COO}^{-}, \mathrm{HCOO}^{-},(\mathrm{COO})_{2}^{2-}, \mathrm{CH}_{3} \mathrm{SO}_{3}^{-}$, $\mathrm{SO}_{4}^{2-}, \mathrm{Cl}^{-}, \mathrm{Br}^{-}, \mathrm{NO}_{3}^{-}, \mathrm{NH}_{4}^{+}, \mathrm{Na}^{+}, \mathrm{K}^{+}, \mathrm{Mg}^{2+}$, and $\mathrm{Ca}^{2+}$ (Moody et al., 2014).

Precipitation sampled during both periods was analyzed for major ionic constituents at UVA. From 1988 to 1997, $\mathrm{H}^{+}$ was measured by electrode and meter, anions $\left(\mathrm{CH}_{3} \mathrm{COO}^{-}\right.$, $\mathrm{HCOO}^{-}, \mathrm{CH}_{3} \mathrm{SO}_{3}^{-}, \mathrm{SO}_{4}^{2-}, \mathrm{Cl}^{-}, \mathrm{Br}^{-}$, and $\mathrm{NO}_{3}^{-}$) were measured by $\mathrm{IC}, \mathrm{NH}_{4}^{+}$was measured by the automated indophenol blue technique, and base cations $\left(\mathrm{Na}^{+}, \mathrm{K}^{+}, \mathrm{Mg}^{2+}\right.$, and $\mathrm{Ca}^{2+}$ ) were measured by AA (Galloway et al., 1993). From 2006 to $2009, \mathrm{H}^{+}$was measured by electrode and meter and the other major ions (the same suite as indicated above for aerosols during this period) were measured by IC using procedures described by Moody et al. (2014).

\subsection{Data quality and comparability}

The quality of data for aerosols and precipitation sampled from 1988 to 1998 is described in detail by Galloway et al. (1993) and Savoie et al. (2002). During both the earlier and later sampling periods, data for aerosol samples that corresponded to in-sector times of less than $2.4 \mathrm{~h}(10 \%$ of a day) exhibit low signal-to-noise and may not be representative; consequently, these results were excluded from the final quality-assured data set. In addition, five samples contained unusually high concentrations of sea-salt constituents (30$380 \%$ higher than the sample with the next highest concentrations) and/or operator notes that suggest direct contamination by rainwater or splash; data for these samples were also excluded from the final quality-assured data set. 
Detection limits (DLs) for all analytes measured from 2006 to 2009 were estimated following Keene et al. (1989). Because in-sector sampling times for aerosols included in the data set varied from 10 to $100 \%$ of the corresponding deployment times, DLs for particulate-phase species varied among samples and, thus, were calculated individually for each analyte in each sample (Moody et al., 2014). Analytical performance was verified by intercomparison of the UVA laboratory with those at UM and the University of New Hampshire, among others; routine analysis of audit solutions from the National Institute of Standards and Technology, the World Meteorological Association, and the US Environmental Protection Agency; periodic analysis of standard additions to samples, and evaluation of ion balances and constituent ratios. These comparisons indicate that the ionic data generated by both UVA and UM are unbiased.

Based on their thermodynamic properties (Henry's law and dissociation constants), the equilibrium phase partitioning of $\mathrm{HNO}_{3}$ and $\mathrm{NH}_{3}$ varies as a function of aerosol solution $\mathrm{pH} ; \mathrm{HNO}_{3}$ partitions preferentially with the less acidic supermicrometer size fractions of marine aerosol whereas $\mathrm{NH}_{3}$ partitions preferentially with the more acidic submicrometer size fractions (e.g., Moody et al., 2014). In addition, larger aerosol size fractions in ambient air may be undersaturated with respect to the gas phase because (1) their surface-tovolume ratios are relatively low and thus equilibration times are relatively slow and (2) they exhibit relatively short atmospheric lifetimes against deposition (e.g., Keene et al., 2004). When chemically distinct marine aerosols are sampled in bulk (or in relatively coarse size fractions) the $\mathrm{pH}$ of the mixed sample may diverge from those for the size fractions with which most $\mathrm{NO}_{3}^{-}$and $\mathrm{NH}_{4}^{+}$was associated in ambient air and thereby drive artifact phase changes (e.g., Keene et al., 1990). Explicit evaluation of the magnitude of such artifacts is beyond the scope of this study but, because different sampling methodologies were employed during the earlier and later periods, artifacts of this nature could influence temporal trends based on measured particulate-phase concentrations of these analytes. We return to this point below. Because $\mathrm{H}_{2} \mathrm{SO}_{4}$ is highly soluble over the reported range in aerosol $\mathrm{pH}$, particulate $\mathrm{SO}_{4}^{2-}$ is not subject to sampling artifacts of this nature.

\subsection{Calculations}

Contributions to measured $\mathrm{SO}_{4}^{2-}$ from sea-salt and non-seasalt sources were differentiated following Keene et al. (1986) for all samples for which the measured concentrations of total $\mathrm{SO}_{4}^{2-}$ and the sea-salt reference species were above DLs. Between 1988 and 1998, non-sea-salt (nss) $\mathrm{SO}_{4}^{2-}$ associated with aerosols was calculated using $\mathrm{Na}^{+}$as the sea-salt references species and the mass ratio of $\mathrm{SO}_{4}^{2-}$ to $\mathrm{Na}^{+}$in surface seawater reported by Millero and Sohn (1992) (0.2516). As indicated above, between 2006 and 2009, super- and submicrometer aerosol size fractions were sampled on $75 \mathrm{~mm}$ and $90 \mathrm{~mm}$ diameter quartz-fiber substrates and filters, respectively. Background concentrations of the two most commonly used sea-salt reference species $\left(\mathrm{Na}^{+}\right.$and $\left.\mathrm{Mg}^{2+}\right)$ in extracts of blanks for the two filter sizes differed such that $\mathrm{Na}^{+}$ offered greater resolution in calculating nss $\mathrm{SO}_{4}^{2-}$ associated with the supermicrometer-diameter aerosol size fraction whereas $\mathrm{Mg}^{2+}$ offered greater resolution for $\mathrm{nss}^{2-} \mathrm{SO}_{4}^{2-}$ associated with the submicrometer-diameter size fraction. Concentrations of super- and submicrometer-diameter nss $\mathrm{SO}_{4}^{2-}$ were calculated accordingly based on the mass ratios of $\mathrm{SO}_{4}^{2-}$ to $\mathrm{Na}^{+}$and $\mathrm{SO}_{4}^{2-}$ to $\mathrm{Mg}^{2+}$ in surface seawater reported by Wilson (1975), (0.2518 and 2.102, respectively). Minor differences between the seawater compositions reported by Millero and Sohn (1992) and Wilson (1975) (less than 0.1\%) used in the above calculations were an insignificant source of bias in resulting nss concentrations. Over the entire period of

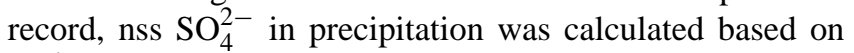
$\mathrm{Na}^{+}$as the reference species and the seawater composition reported by Wilson (1975).

Concentrations of ionic species associated with super- and submicrometer-diameter aerosol size fractions measured during the period 2006-2009 were summed (Moody et al., 2014) for comparison with the chemical composition of aerosol sampled in bulk during the earlier period of record. To evaluate temporal trends over the entire period of record, data were binned into sample years based on the midpoint of the each daily sampling interval. Aerosol constituents are reported as annual average concentrations and precipitation constituents are reported as VWA (volume-weighted-average) concentrations. FLEXPART (FLEXible PARTicle dispersion model) retroplumes (see below) were not available to characterize transport for the samples collected prior to 1 January 1989. Consequently, from 1989 to 1997, sample years were defined as 1 January-31 December and temporal trends were interpreted based on the corresponding mid-year date of 1 July. Because the later 3 year period of record started in mid-2006 and ended in mid-2009, sample years were defined as 1 July30 June and interpreted based on the mid-year date of 1 January. This approach yielded 3 full (12 month) sample years over the period of record. If based on calendar year, the last 6 months of 2006 and the first 6 months of 2009 would have been excluded yielding only 2 years for the analysis.

\subsection{Atmospheric transport}

The particle dispersion model FLEXPART (Stohl et al., 1998, 2005) was run in backward mode (Stohl et al., 2003; Seibert and Frank, 2004) to generate the column residence times and footprint residence plots for source regions associated with the sampled air parcels. FLEXPART was driven with ECMWF (European Centre for Medium-Range Weather Forecasts) analyses of $0.36^{\circ}$ resolution and accounts for turbulence and deep convection in addition to the transport by grid-resolved winds. At 15:00 UTC (universal coordinated time; the approximate midpoint of the deployment times for 
aerosol and precipitation samplers), 40000 particles were released from the location of the measurement site and followed backward in time for 10 days. Primary flow regimes were characterized based on proportional footprint residence times within four prescribed source regions from which air was transported to Bermuda. See Moody et al. (2014) for detailed explanation of the procedure employed to identify primary air-mass source regions for aerosols sampled at Bermuda during the period 2006-2009 and examples of retroplumes for each flow regime. An identical approach was applied to characterize source regions for aerosols sampled during the period 1989-1997 and for precipitation sampled during both periods. Wind fields were not available for the first 6 months of 1990. Because retroplumes could not be calculated for that period, annual statistics for 1990 were not included in the evaluation of trends associated with air transported from different source regions.

Moody et al. (2014) identified two distinct flow regimes that transported aerosols from eastern North America to Bermuda. One was associated with predominant flow from the northeastern United States (NEUS) and southern Canada and the other with predominant flow from southeastern US (SEUS) and the Gulf of Mexico. To evaluate trends associated with the combined flow off northern and southern regions of eastern North America, the NEUS and SEUS flow regimes were merged for this analysis into a single group (referred to as "NEUS/SEUS"). Transport from northern Africa and the tropical NAO region (referred to as "Africa") was associated with trade-wind flow along the southern portion of the Bermuda High (BH). The "Oceanic" flow regime was generally associated with long trajectories over the open ocean under anticyclonic flow around the BH. The "North" transport regime represented transitional flow from the relatively clean open ocean to the polluted eastern North America. Data evaluated herein were classified accordingly; the total numbers of samples and corresponding mean precipitation amounts in the final database partitioned by flow regime and year are summarized in Table 1 . The relatively fewer number of aerosol samples for the period 2006-2009 reflects the fact that (1) dichotomous rather than bulk aerosol was sampled during the later period and thus the super- and submicrometer-diameter size fractions of each sample were segregated and analyzed separately, and (2) sampling rates through the high-flow impactor were a factor of 10 lower that those through the high-volume bulk sampler. Although analytical resolution per unit analyte concentration in extract solutions was higher during the latter period, the absolute amount of analyte present in each size fraction was lower relative to bulk aerosol during the earlier part of the record. Consequently, relatively fewer aerosol constituents were present in samples at concentrations above DLs during the period 2006-2009.

\subsection{Statistical evaluations}

The statistical package SPSS was used to evaluate temporal trends in the data using two complimentary approaches. (1) Trends were characterized based on slopes of standard linear regressions (SLRs) for annual average concentrations of aerosol constituents versus time and for annual VWA concentrations of precipitation constituents versus time. (2) Temporal trends in annual mean (for aerosols) and annual VWA (for precipitation) constituent concentrations were also characterized based on slopes calculated using the bootstrapping method applied to all individual daily data (Freedman, 1981). The significance of each bootstrap slope was evaluated using a two-tailed test based on 1000 random samples of the corresponding data subset. Relative to SLRs, this method provides a more robust evaluation of significance in trends. For smaller data sets, the approach resulted in redundant subsampling. In these cases the actual significance thresholds may have deviated somewhat from the calculated values. However, sensitivity evaluations employing smaller numbers of random samples yielded virtually identical results suggesting that any such deviations were small to negligible. Interannual variability in mean or VWA constituent concentrations is the only source of variance in the SLRs whereas seasonal variability contributes significantly to overall variance based on the bootstrap method. Consequently, substantially less overall variance in long-term trends is explained by bootstrapping. Because this analysis focuses on long-term trends, reported variances correspond to those for SLRs.

In addition to the calculations summarized above, trends in annual median aerosol and precipitation concentrations and in per-event wet-deposition fluxes were also quantified for selected data subsets to evaluate the sensitivity of results to the underlying sample statistics used in the analysis. Results were reasonably consistent with those based on annual mean concentrations for aerosols and annual VWA concentrations for precipitation. We interpret results based on the latter, more widely used conventions for reporting and evaluating concentrations of aerosol and precipitation constituents thereby facilitating direct comparison with previously published results.

\section{Results and discussion}

\subsection{Temporal trends in the chemical composition of aerosols and precipitation}

Temporal trends in annual average concentrations of particulate nss $\mathrm{SO}_{4}^{2-}, \mathrm{NO}_{3}^{-}$, and $\mathrm{NH}_{4}^{+}$and corresponding trends in annual VWA concentrations in precipitation based on all quality-assured data over the period of record at Bermuda are depicted in Fig. 1. Nss $\mathrm{SO}_{4}^{2-}$ concentrations for both aerosols and precipitation decreased significantly but the percentage 
Table 1. Numbers $(N)$ of daily aerosol and precipitation samples and mean precipitation amounts $(\mathrm{cm})$ per sample for all data evaluated in this study partitioned by flow regime and year. Annual data from 1989 to 1997 are binned by calendar year (1 January-31 December) and those from 2006 to 2009 are binned from 1 July to 30 June.

\begin{tabular}{|c|c|c|c|c|c|c|c|c|c|c|c|c|c|}
\hline Mid-year & 1989 & 1990 & 1991 & 1992 & 1993 & 1994 & 1995 & 1996 & 1997 & 2007 & 2008 & 2009 & All \\
\hline \multicolumn{14}{|l|}{ Aerosols, $N$} \\
\hline All data ${ }^{1}$ & 168 & 184 & 199 & 186 & 130 & 152 & 174 & 182 & 215 & 113 & 111 & 84 & 1898 \\
\hline NEUS/SEUS & 119 & N/A & 136 & 107 & 95 & 101 & 104 & 132 & 133 & 64 & 68 & 54 & 1113 \\
\hline Africa & 30 & N/A & 41 & 45 & 24 & 28 & 40 & 32 & 49 & 26 & 30 & 22 & 367 \\
\hline Oceanic & 9 & N/A & 11 & 17 & 3 & 11 & 9 & 8 & 10 & 6 & 8 & 5 & 97 \\
\hline North & 10 & N/A & 11 & 17 & 8 & 12 & 21 & 10 & 23 & 17 & 5 & 3 & 137 \\
\hline \multicolumn{14}{|c|}{ Precipitation, $N$} \\
\hline All data ${ }^{2}$ & 101 & 72 & 71 & 70 & 76 & 82 & 76 & 84 & N/A & 99 & 100 & 86 & 917 \\
\hline NEUS/SEUS & 59 & N/A & 43 & 37 & 51 & 46 & 42 & 53 & N/A & 61 & 55 & 40 & 487 \\
\hline Africa & 34 & N/A & 15 & 17 & 17 & 19 & 17 & 20 & N/A & 19 & 21 & 34 & 213 \\
\hline Oceanic & 5 & N/A & 5 & 9 & 3 & 7 & 7 & 6 & N/A & 10 & 11 & 6 & 69 \\
\hline North & 3 & N/A & 8 & 7 & 5 & 10 & 10 & 5 & N/A & 9 & 13 & 6 & 76 \\
\hline \multicolumn{14}{|c|}{ Precipitation amount, $\mathrm{cm}$} \\
\hline All data & 0.87 & 1.08 & 1.09 & 1.15 & 1.66 & 1.39 & 1.06 & 1.08 & N/A & 0.94 & 1.02 & 0.83 & 1.09 \\
\hline NEUS/SEUS & 0.81 & N/A & 0.89 & 1.08 & 1.71 & 1.36 & 1.21 & 1.06 & N/A & 0.95 & 1.05 & 0.79 & 1.09 \\
\hline Africa & 1.02 & N/A & 1.07 & 1.35 & 1.36 & 1.32 & 0.97 & 1.43 & N/A & 1.07 & 1.02 & 0.77 & 1.10 \\
\hline Oceanic & 0.90 & N/A & 0.56 & 1.28 & 1.00 & 1.93 & 1.06 & 0.51 & N/A & 1.11 & 0.76 & 0.99 & 1.03 \\
\hline North & 0.35 & N/A & 2.53 & 0.90 & 2.49 & 1.31 & 0.60 & 0.57 & N/A & 0.36 & 1.14 & 1.31 & 1.16 \\
\hline
\end{tabular}

N/A indicates that either the chemical data or the corresponding FLEXPART retroplumes were not available for the indicated period (see text).

${ }^{1}$ Numbers correspond to particulate nss $\mathrm{SO}_{4}^{2-}, \mathrm{NO}_{3}^{-}$, and $\mathrm{NH}_{4}^{+}$; for particulate $\mathrm{CH}_{3} \mathrm{SO}_{3}^{-}$, total $\mathrm{N}$ was 1266 due to the shorter period of record and relatively fewer samples with concentrations greater than DLs.

${ }^{2}$ Numbers correspond to $\mathrm{nss}_{4}^{2-}, \mathrm{NO}_{3}^{-}$, and $\mathrm{NH}_{4}^{+}$in precipitation; for $\mathrm{CH}_{3} \mathrm{SO}_{3}^{-}$in precipitation, total $N$ was 845 due to the relatively fewer samples with concentrations greater than DLs.

decrease in VWA concentrations based on the SLR for precipitation (49\%) was greater than the corresponding decrease in annual mean concentrations for aerosols $(24 \%$, Table 2). In contrast, the VWA concentration of $\mathrm{NH}_{4}^{+}$in precipitation increased significantly $(70 \%)$ over the period of record whereas the trend in particulate $\mathrm{NH}_{4}^{+}$was insignificant (Table 2). Concentrations of $\mathrm{NO}_{3}^{-}$associated with aerosols and precipitation also did not vary significantly (Table 2). These results suggest long-term changes in atmospheric composition and also indicate that relative trends in the composition of precipitation and near-surface aerosols diverge. However, substantial interannual variability is evident for all species in both phases (Fig. 1a, b) and the corresponding linear regressions explain less than $50 \%$ of the variance over the period of record.

\subsection{Temporal trends based on FLEXPART flow patterns}

Year-to-year variability in frequencies of transport from different source regions is one of the major factors that drives interannual variability in atmospheric composition at a given location. Such influences can be minimized by evaluating trends in concentrations as a function of transport regime.
As was the case for the data subset corresponding to aerosols sampled from 2006 to 2009 (Moody et al., 2014), segregation by source region differentiated analyte concentrations into chemically distinct subgroups. For most years, the upper limits for mean concentrations of aerosol and precipitation constituents were associated with polluted NEUS/SEUS flow from North America whereas the lower limits were associated with background Oceanic flow around the BH (Fig. 2). Analytes associated with the Africa and North flow regimes generally fell within the range bounded by the other two regimes. However, numbers of samples per year varied substantially among flow regimes (Table 1). The relatively small numbers of samples collected under Oceanic and North flow in particular constrain the power of statistical approaches for evaluating associated temporal trends and thus caution is warranted in their interpretation.

Because regional transport varies seasonally, segregating data by source region also segregated to some extent by season. For example, efficient transport of North American emissions over the western NAO is typically associated with frontal passages, which are most frequent during winter and spring, whereas transport from Northern Africa to the western NAO in association with the easterly trade wind regime is most frequent during summer. Factors other than precursor 
Table 2. Regression statistics and, for significant trends, percent changes in concentrations over the period of record.

\begin{tabular}{|c|c|c|c|c|c|c|c|c|}
\hline $\begin{array}{l}\text { Species/ } \\
\text { flow regime }\end{array}$ & $\begin{array}{c}\text { Bootstrap slope } \\
\text { (std. error) } \\
\left(\mathrm{nmol} \mathrm{m}^{-3} \mathrm{yr}^{-1}\right)\end{array}$ & $\begin{array}{l}\text { SLR slope } \\
(\mathrm{nmol} \\
\left.\mathrm{m}^{-3} \mathrm{yr}^{-1}\right)\end{array}$ & $\begin{array}{l}\text { SLR } \\
r^{2}\end{array}$ & $\begin{array}{c}\text { SLR } \\
\text { change }^{1} \\
(\%)\end{array}$ & $\begin{array}{c}\text { Bootstrap slope } \\
\text { (std. error) } \\
\left(\mu \mathrm{mol} \mathrm{L}-1 \mathrm{yr}^{-1}\right)\end{array}$ & $\begin{array}{c}\text { SLR slope } \\
\left(\mu \mathrm{mol} \mathrm{L}^{-1} \mathrm{yr}^{-1}\right)\end{array}$ & $\begin{array}{c}\text { SLR } \\
r^{2}\end{array}$ & $\begin{array}{c}\text { SLR } \\
\text { change }^{1} \\
(\%)\end{array}$ \\
\hline & & Aerosol & & & & Precipitation & & \\
\hline \multicolumn{9}{|l|}{ nss $\mathrm{SO}_{4}^{2-}$} \\
\hline All data & $-0.26(0.08)^{*}$ & -0.24 & 0.17 & $-22 \%$ & $-0.10(0.03)^{*}$ & -0.11 & 0.67 & $-49 \%$ \\
\hline NEUS/SEUS & $-0.16(0.11)$ & -0.12 & - & - & $-0.16(0.05)^{*}$ & -0.17 & 0.61 & $-61 \%$ \\
\hline Africa & $-0.28(0.12)^{*}$ & -0.31 & 0.29 & $-34 \%$ & $-0.06(0.06)$ & -0.06 & - & - \\
\hline Oceanic & $0.14(0.12)$ & 0.14 & - & - & $-0.09(0.03)^{*}$ & -0.08 & 0.31 & $-61 \%$ \\
\hline North & $0.36(0.34)$ & 0.22 & - & - & $0.10(0.06)$ & 0.04 & - & - \\
\hline \multicolumn{9}{|l|}{$\mathrm{NO}_{3}^{-}$} \\
\hline All data & $-0.01(0.05)$ & -0.01 & - & - & $0.05(0.03)$ & 0.04 & - & - \\
\hline NEUS/SEUS & $0.03(0.07)$ & 0.03 & - & - & $0.02(0.05)$ & 0.01 & - & - \\
\hline Africa & $-0.12(0.06)^{* *}$ & -0.13 & 0.26 & $-20 \%$ & $0.08(0.05)$ & 0.07 & - & - \\
\hline Oceanic & $0.17(0.09)^{* *}$ & 0.18 & 0.53 & $46 \%$ & $0.06(0.05)$ & 0.06 & - & - \\
\hline North & $0.23(0.17)$ & 0.31 & - & - & $0.17(0.06)^{*}$ & 0.13 & 0.32 & $76 \%$ \\
\hline \multicolumn{9}{|l|}{$\mathrm{NH}_{4}^{+}$} \\
\hline All data & $-0.05(0.08)$ & -0.06 & - & - & $0.08(0.03)^{*}$ & 0.08 & 0.68 & $70 \%$ \\
\hline NEUS/SEUS & $0.05(0.10)$ & 0.04 & - & - & $0.08(0.05)$ & 0.09 & - & - \\
\hline Africa & $-0.33(0.11)^{*}$ & -0.33 & 0.35 & $-44 \%$ & $0.09(0.05)^{* *}$ & 0.09 & 0.48 & $102 \%$ \\
\hline Oceanic & $0.05(0.16)$ & 0.09 & - & - & $0.03(0.03)$ & 0.03 & - & - \\
\hline North & $0.15(0.26)$ & 0.05 & - & - & $0.09(0.06)$ & 0.05 & - & - \\
\hline
\end{tabular}

$* p=0.05 ;$ significant at $95 \%$ confidence.

** $p=0.10$; significant at $90 \%$ confidence.

${ }^{1}$ Percent change over the period of record relative to 1989 based on the SLR slope.

emissions within and the frequencies of flow from source regions also contribute to seasonal variability in aerosol and precipitation composition among flow regimes. Relative to colder months, higher ultraviolet radiation and temperatures during warmer months sustain faster rates of precursor oxidation and secondary aerosol production. The temperaturedependent emissions of $\mathrm{NH}_{3}$ contribute to seasonal variability in the nucleation and growth of new particles. Seasonal variability in precipitation fields and in the temperaturedependent partitioning of semivolatile species between the gas and particulate phases also drive seasonal variability in atmospheric lifetimes and associated transport and deposition fields. Although these and other processes contribute to overall variability in aerosol and precipitation composition as a function of source region, our data lack adequate resolution to quantitatively differentiate relative influences. See Moody et al. (2014) for a detailed evaluation of seasonal variability in the sources and composition of aerosols at Bermuda between 2006 and 2009.

\subsection{1 nsS $\mathrm{SO}_{4}^{2-}$}

Based on slopes for SLRs fit to annual average concentrations, VWA nss $\mathrm{SO}_{4}^{2-}$ in precipitation associated with the NEUS/SEUS flow regime decreased significantly (61\%) over the period of record whereas the corresponding trend in particulate $\mathrm{nss}^{2-} \mathrm{SO}_{4}^{2-}$ was marginally insignificant $(p=0.12$; Fig. 2a, b; Table 2). The absence of a significant trend in particulate nss $\mathrm{SO}_{4}^{2-}$ for the NEUS/SEUS flow was driven in part by the missing data for 1990. Based on all data (Fig. 1a), 1990 exhibited the highest mean concentration over the period and most samples during each year were associated with the NEUS/SEUS regime (Table 1). Between 1989 and 2009, $\mathrm{SO}_{2}$ emitted over the US and Canada decreased by $60 \%$ (Fig. 3). Although the overall decrease in VWA nss $\mathrm{SO}_{4}^{2-}$ in precipitation based on the SLR was similar to that for $\mathrm{SO}_{2}$ emissions over the US and Canada during the period of record, the temporal patterns within the period of record were distinct. Most of the decrease in VWA nss $\mathrm{SO}_{4}^{2}$ was associated with a significant negative trend between 1991 and 1996 (SLR slope $=-0.62 \mu \mathrm{mol} \mathrm{L}^{-1} \mathrm{yr}^{-1}$, $r^{2}=0.84$; Fig. 2b). Based on the SLR from 1991 to 1996 , annual VWA nss $\mathrm{SO}_{4}^{2-}$ during the period decreased by $51 \%$ whereas, over the same period, $\mathrm{SO}_{2}$ emissions in the US and Canada decreased by only $17 \%$ (Fig. 3). It is evident from the above that (1) the declines in nss $\mathrm{SO}_{4}^{2-}$ associated with both near-surface aerosols and precipitation under NEUS/SEUS flow were not directly proportional to the decline in $\mathrm{SO}_{2}$ 

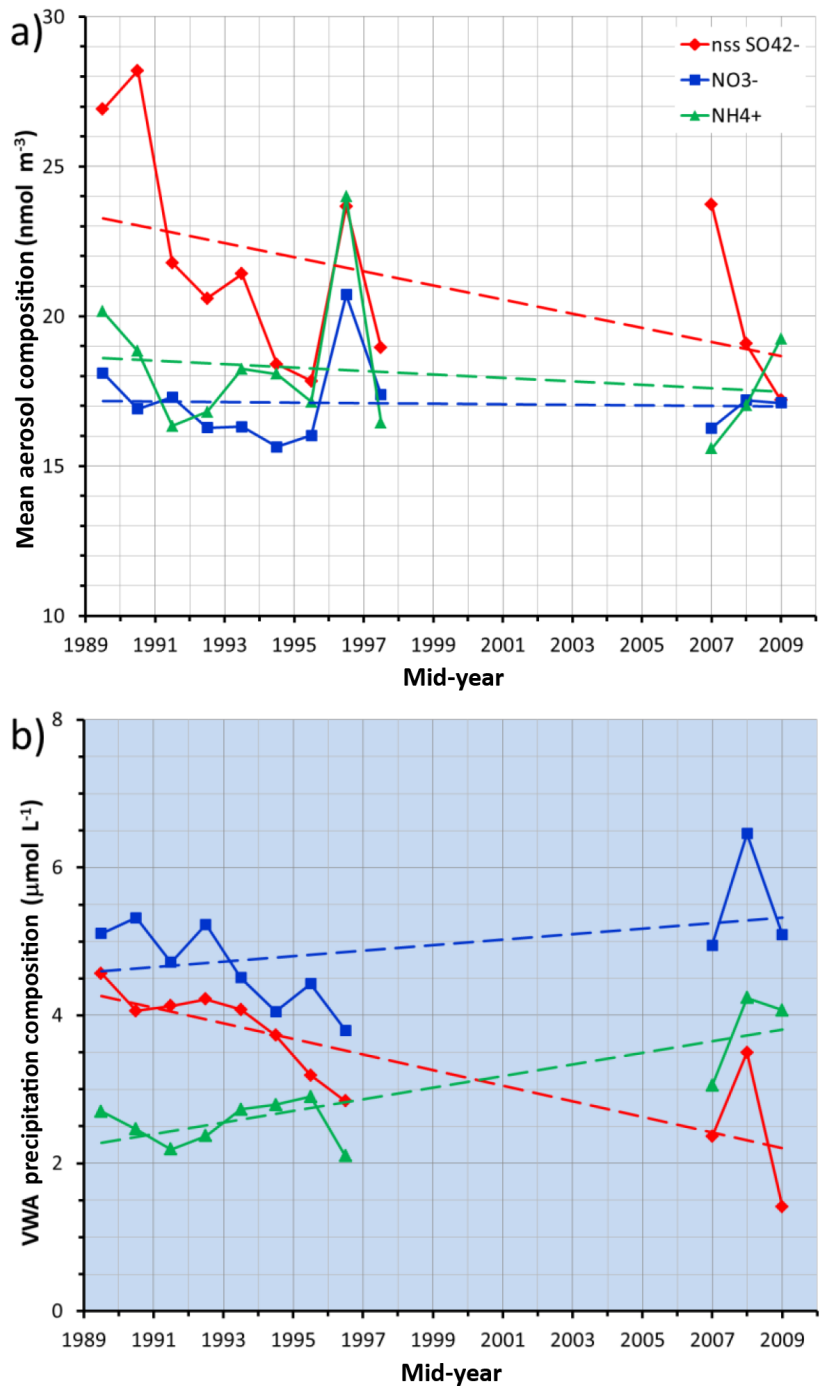

Figure 1. Temporal trends in (a) annual average concentrations of bulk particulate nss $\mathrm{SO}_{4}^{2-}$ (red), $\mathrm{NO}_{3}^{-}$(blue), and $\mathrm{NH}_{4}^{+}$(green) in near-surface air (white backgrounds) and (b) corresponding annual VWA concentrations in precipitation (light-blue backgrounds) at Bermuda based on all quality-assured data generated over the period of record. Color-coded dashed lines correspond to SLRs for annual averages and VWAs versus time.

emissions over the US and Canada and (2) factors other than $\mathrm{SO}_{2}$ emissions over the North American source region influenced trends in nss $\mathrm{SO}_{4}^{2-}$ associated with near-surface aerosols and precipitation under NEUS/SEUS flow differentially.

Significant amounts of nss $\mathrm{SO}_{4}^{2-}$ associated with aerosols and precipitation at Bermuda originate from the atmospheric oxidation of dimethylsulfide $\left(\left(\mathrm{CH}_{3}\right)_{2} \mathrm{~S}\right)$ produced in the surface ocean by marine biota and subsequently emitted to the atmosphere (Galloway et al., 1989; Savoie et al., 2002; Moody et al., 2014). Potential variability in biogenic contributions may have contributed to the differences in trends noted above. To evaluate potential influences of biogenic

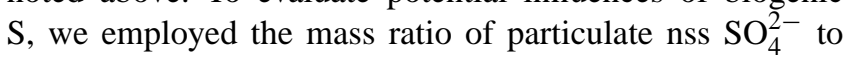
$\mathrm{CH}_{3} \mathrm{SO}_{3}^{-}$yields from $\left(\mathrm{CH}_{3}\right)_{2} \mathrm{~S}$ oxidation estimated from measurements at Bermuda (18.8 \pm 2.2 , Savoie et al., 2002) to differentiate relative contributions from marine biogenic and anthropogenic sources to annual average concentrations of particulate nss $\mathrm{SO}_{4}^{2-}$ associated with NEUS/SEUS flow (Fig. 4a). Briefly, in mass units, anthropogenic nss $\mathrm{SO}_{4}^{2-}$ was estimated from total $\mathrm{nss} \mathrm{SO}_{4}^{2-}$ minus the product $\mathrm{CH}_{3} \mathrm{SO}_{3}^{-} \cdot 18.8$. Corresponding trends in annual VWA nss $\mathrm{SO}_{4}^{2-}$ in precipitation were calculated (Fig. $4 \mathrm{~b}$ ) based on the assumption that the same product yields apply to precipitation. Trends in $\mathrm{CH}_{3} \mathrm{SO}_{3}^{-}$(and thus biogenic contributions) for both aerosols and precipitation were insignificant, which

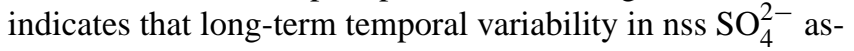
sociated with both aerosols and precipitation was driven primarily by differential variability in anthropogenic contributions. These results also indicate that relative contributions of anthropogenic sources to VWA nss $\mathrm{SO}_{4}^{2-}$ in precipitation at Bermuda have decreased more rapidly that those to mean nss $\mathrm{SO}_{4}^{2-}$ associated with aerosols (Fig. 4). For example, based on the corresponding SLRs, percentage contributions of anthropogenic sources to nss $\mathrm{SO}_{4}^{2-}$ in precipitation and aerosols under NEUS/SEUS flow were roughly similar during the first sample year centered on 1 July 1989 (73\% and $72 \%$, respectively) whereas they diverge to a greater degree by the final sample year centered on 1 January 2009 (41\% and $68 \%$, respectively). We return to this issue below.

VWA nss $\mathrm{SO}_{4}^{2-}$ associated with the Oceanic flow regime decreased significantly whereas the corresponding trend in particulate nss $\mathrm{SO}_{4}^{2-}$ was insignificant (Fig. 2a, b; Table 2). Available evidence suggests that virtually all particulate nss $\mathrm{SO}_{4}^{2-}$ in near-surface air sampled under Oceanic flow at Bermuda between 2006 and 2009 originated from the oxidation of $\left(\mathrm{CH}_{3}\right)_{2} \mathrm{~S}$ (Moody et al., 2014). Corresponding trends in $\mathrm{CH}_{3} \mathrm{SO}_{3}^{-}$associated with both aerosols and precipitation sampled under Oceanic flow over the entire period of record were insignificant. However, the relatively small numbers of observations per year (Table 1) coupled with seasonal variability in $\mathrm{CH}_{3} \mathrm{SO}_{3}^{-}$concentrations (Moody et al., 2014) constrains resolution in explicitly evaluating biogenic versus anthropogenic contributions to total nss $\mathrm{SO}_{4}^{2-}$ for this regime based on product yields as was done for the NEUS/SEUS regime. However, the similarities in annual mean particulatephase nss $\mathrm{SO}_{4}^{2-}$ under Oceanic flow during both the earlier and later periods of record (as reflected in the corresponding lack of a significant trend) indicates that the background particulate $\mathrm{nss} \mathrm{SO}_{4}^{2-}$ from biogenic sources in near-surface aerosol remained fairly constant over this 20 -year period. In contrast, VWA nss $\mathrm{SO}_{4}^{2-}$ in precipitation sampled under the same flow regime exhibited significant decreasing concentrations. Most nss $\mathrm{SO}_{4}^{2-}$ in precipitation originates from the aqueous-phase oxidation of $\mathrm{SO}_{2}$ in cloud droplets and scavenging of particulate nss $\mathrm{SO}_{4}^{2-}$ from the air column (e.g., 

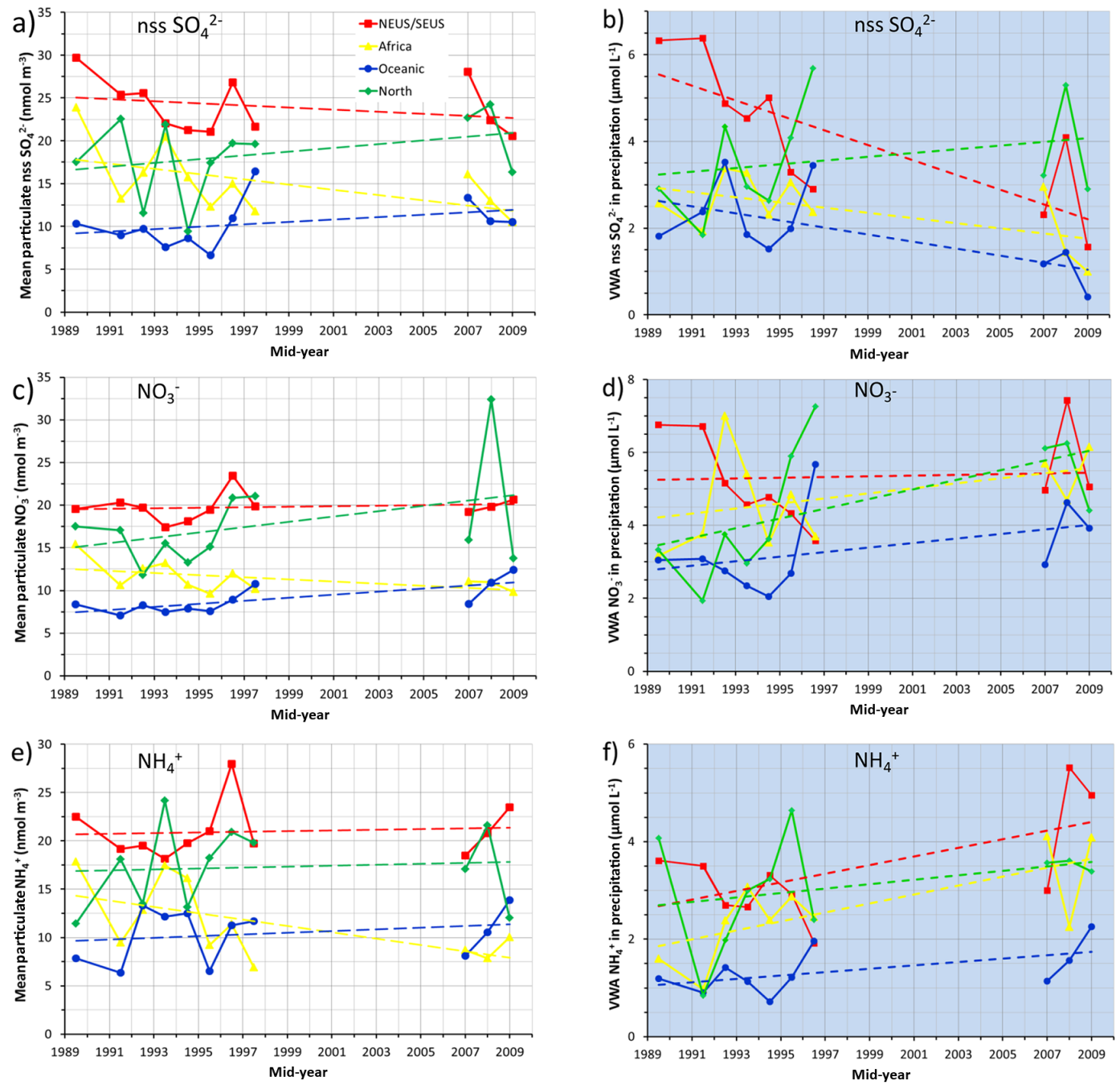

Figure 2. Temporal trends in annual average concentrations of bulk particulate (a) nss $\mathrm{SO}_{4}^{2-}$, (c) $\mathrm{NO}_{3}^{-}$, and (e) $\mathrm{NH}_{4}^{+}$in near-surface air (white backgrounds) and annual VWA concentrations of (b) nss $\mathrm{SO}_{4}^{2-}$, (d) $\mathrm{NO}_{3}^{-}$, and (f) $\mathrm{NH}_{4}^{+}$in precipitation (light-blue backgrounds) associated with NEUS/SEUS (red), African (yellow), Oceanic (blue), and North (green) flow regimes. Color-coded dashed lines correspond to SLRs for annual mean and VWA concentrations versus time.

Mari et al., 2000; von Glasow et al., 2002) whereas aerosols evaluated herein were sampled near the surface. Our results suggest the possibility that the transport of pollutant S emitted from surrounding continents sustained relatively higher concentrations of oxidized $\mathrm{S}$ in aged marine air aloft, which contributed significantly to $\mathrm{nss} \mathrm{SO}_{4}^{2-}$ incorporated into precipitation but not into near-surface aerosols under Oceanic flow. As anthropogenic emissions from surrounding continents decreased over the period of record, contributions of pollutant $\mathrm{S}$ to background concentrations in aged marine air aloft over the NAO would have also decreased thereby contributing to the observed decline (61\%) in VWA nss $\mathrm{SO}_{4}^{2-}$ in precipitation sampled under Oceanic flow (Fig. 2b; Table 2).

The larger decrease in VWA nss $\mathrm{SO}_{4}^{2-}$ associated with precipitation relative to aerosols in NEUS/SEUS flow discussed above would be consistent with our interpretation of trends for the Oceanic regime. Air masses transported off eastern North America over the western NAO may rise up over and become decoupled from the marine boundary layer (MBL) (Neuman et al., 2006) whereas most biogenic $\left(\mathrm{CH}_{3}\right)_{2} \mathrm{~S}$ emitted from the ocean surface is oxidized within the MBL (e.g., Savoie et al., 2002). Most $\mathrm{SO}_{2}$ in the MBL is oxidized to particulate $\mathrm{H}_{2} \mathrm{SO}_{4}$ via aqueous-phase pathways involving supermicrometer marine aerosols that have short lifetimes against deposition and cloud droplets (e.g., Keene et al., 1998; von Glasow et al., 2002). In addition, both $\mathrm{SO}_{2}$ and submicrom-

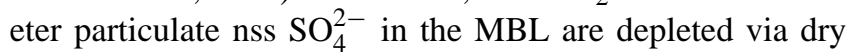
deposition to the surface ocean. Consequently, oxidized $\mathrm{S}$ above the western NAO MBL, which available evidence suggests is primarily anthropogenic, should exhibit longer atmospheric lifetimes against removal relative to that within the MBL, which includes most of the biogenic component. 


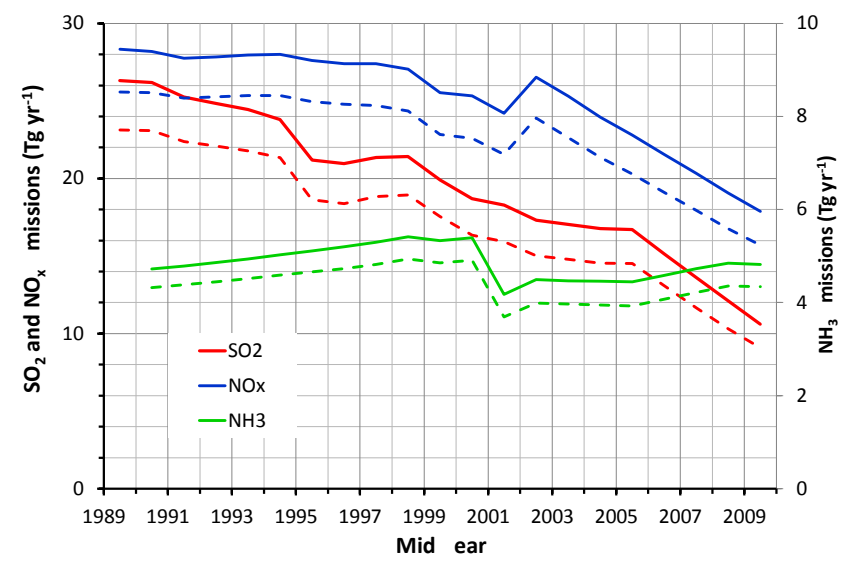

Figure 3. Temporal trends in $\mathrm{SO}_{2}$ (red), $\mathrm{NO}_{\mathrm{x}}$ (blue), and $\mathrm{NH}_{3}$ (green) emitted to the atmosphere over the continental US (EPA, 2013) and over the continental US (EPA, 2013, dashed lines) and over the continental US plus Canada (Environment Canada, 2014; solid lines) during the period of this study.

We hypothesize that the differential vertical distributions and associated atmospheric lifetimes of oxidized S from anthropogenic versus biogenic sources coupled with reductions in anthropogenic emissions contributed to relatively greater proportionate decreases in anthropogenic contributions to $\mathrm{nss} \mathrm{SO}_{4}^{2-}$ in precipitation versus near-surface aerosols over

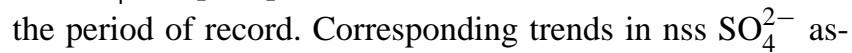
sociated with both aerosols and precipitation sampled under North flow were insignificant (Fig. 2a, b; Table 2) but the relatively small numbers of observations (Table 1) constrains resolution and, thus, caution is warranted in interpreting these results.

Particulate nss $\mathrm{SO}_{4}^{2-}$ associated with the Africa flow regime decreased significantly $(34 \%)$ over the period of record (Fig. 2a; Table 2). Based on the SLR, corresponding VWA nss $\mathrm{SO}_{4}^{2-}$ concentrations in precipitation under Africa flow generally decreased, but unlike aerosols, this trend was not significant (Fig. 2b; Table 2). As was the case for the NEUS/SEUS regime, the temporal trends in biogenic nss $\mathrm{SO}_{4}^{2-}$ (inferred from $\mathrm{CH}_{3} \mathrm{SO}_{3}^{-}$as described above) were statistically indistinguishable from 0.0 for both aerosols (SLR slope $=-0.007 \mathrm{nmol} \mathrm{m}^{-3} \mathrm{yr}^{-1}$ ) and precipitation (SLR slope $=-0.006 \mu \mathrm{mol} \mathrm{L}^{-1} \mathrm{yr}^{-1}$ ), which implies that reductions in anthropogenic contributions drove the decreasing trends in nss $\mathrm{SO}_{4}^{2-}$. We hypothesize that large reductions in $\mathrm{SO}_{2}$ emissions over Europe (Vestreng et al., 2007) coupled with transport over the subtropical NAO in association with the easterly trade winds (e.g., Savoie et al., 1989) contributed to the trend of decreasing particulate $\mathrm{nss} \mathrm{SO}_{4}^{2-}$ for the Africa regime. However, unlike the differences in trends under NEUS/SEUS flow discussed above, proportionate decreases in $\mathrm{nss}^{\mathrm{SO}_{4}^{2-}}$ associated with aerosols and precipitation under Africa flow based on the SLR slopes (Fig. 2a, b) were of roughly similar magni-
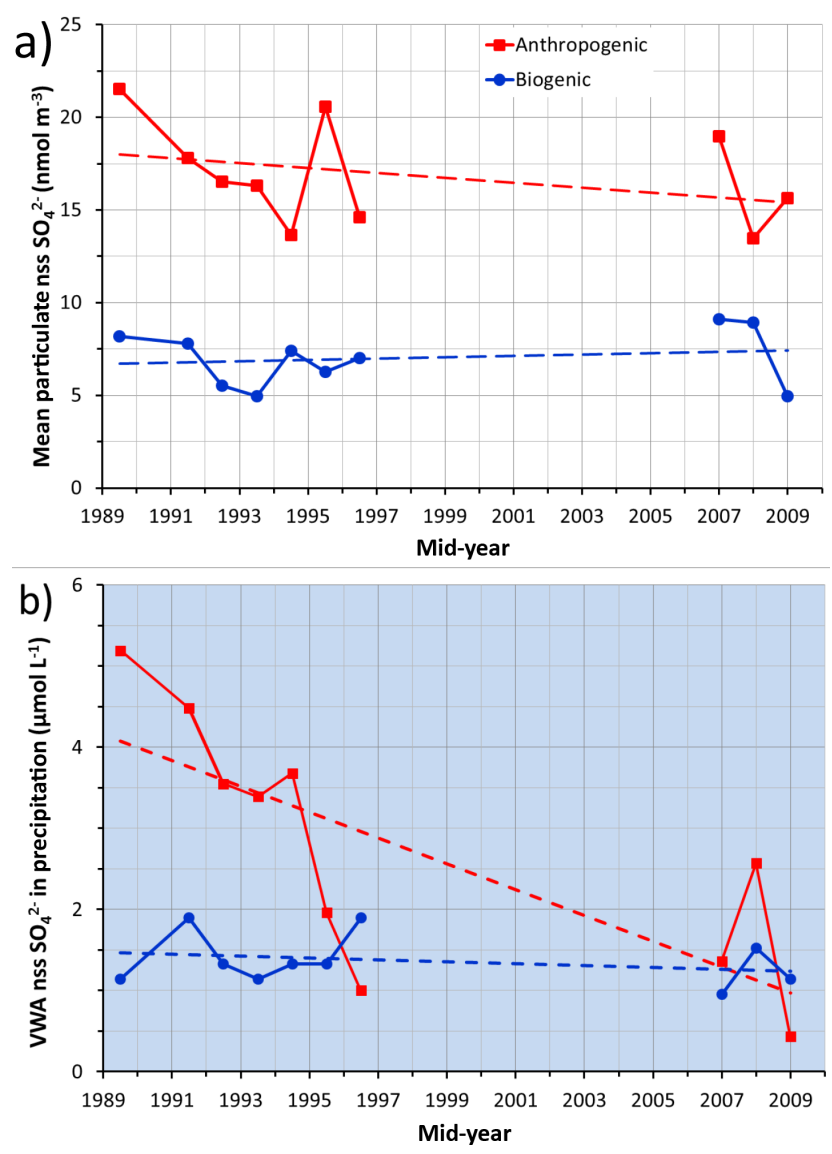

Figure 4. Temporal trends in anthropogenic and biogenic contributions to nss $\mathrm{SO}_{4}^{2-}$ associated with (a) aerosols (white backgrounds) and (b) precipitation (light-blue backgrounds) sampled under NEUS/SEUS flow.

tude. Several factors may have contributed to differences in temporal trends for aerosols versus precipitation based on available data for the two regimes. Anthropogenic contributions to nss $\mathrm{SO}_{4}^{2-}$ under Africa flow were significantly less than those under NEUS/SEUS flow (Moody et al., 2014). Based on the SLR for total particulate $\mathrm{nss}^{2-} \mathrm{SO}_{4}^{2-}$ under Africa flow (Fig. 2a; Table 2) and that for the corresponding anthropogenic component calculated as described above (not

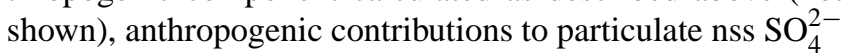
decreased from 46 to $19 \%$ between 1989 and 2008-2009. Based on the SLRs, the corresponding decrease for precipitation was of roughly similar magnitude $(40-8 \%)$. Relative to the NEUS/SEUS, the lower absolute contributions of anthropogenic $S$ to an interannually variable background of biogenic $\mathrm{S}$ afforded less resolution in evaluating trends for the Africa regime. In addition, available observations under Africa flow were relatively less frequent (Table 1), which further constrained resolution. Relatively longer transport times to Bermuda from Europe and Africa versus North America 
as well as differences in associated atmospheric dynamics for the two flow regimes may have also contributed to differences in trends. For example, during transport over the ocean, losses of biogenic $\mathrm{S}$ via deposition to the surface are continually replaced via oxidation of marine-derived $\left(\mathrm{CH}_{3}\right)_{2} \mathrm{~S}$ whereas losses of anthropogenic S are not. Consequently, vertical gradients in the relative abundance of oxidized $S$ from anthropogenic versus biogenic sources and the corresponding differences in ratios of anthropogenic to biogenic $\mathrm{S}$ scavenged from the column by precipitation versus those for near-surface aerosols would be expected to decrease with distance from anthropogenic source regions. Finally, to the extent that interactions with mineral aerosol influence the atmospheric lifetime of oxidized S against deposition, longterm temporal variability in mineral aerosol under transport from Africa to the western NAO (e.g., Evan et al., 2006) may have modulated the trend in associated particulate $\mathrm{nss}^{\mathrm{SO}_{4}^{2-}}$ relative to that for the NEUS/SEUS regime.

\subsection{2 $\mathrm{NO}_{3}^{-}$}

Under NEUS/SEUS flow, trends based on SLRs fit to $\mathrm{NO}_{3}^{-}$ concentrations associated with both aerosols and precipitation over the entire period of record were insignificant (Fig. 2c, d; Table 2). In contrast, emissions of $\mathrm{NO}_{\mathrm{x}}$ over the US and Canada decreased by $37 \%$ during this period (Fig. 3). The reported increase in $\mathrm{NO}_{\mathrm{x}}$ emissions in the US between 2001 and 2002 reflects an artifact that resulted from a change in the method used to estimate road emissions (R. L. Dennis, US EPA, personal communication, 2014). Like VWA nss $\mathrm{SO}_{4}^{2-}$ in precipitation at Bermuda, the corresponding VWA $\mathrm{NO}_{3}^{-}$also decreased significantly between 1991 and 1996 (SLR slope $=-0.50 \mu \mathrm{mol} \mathrm{L}^{-1} \mathrm{yr}^{-1}, r^{2}=0.83$ ) but, unlike nss $\mathrm{SO}_{4}^{2-}, \mathrm{NO}_{3}^{-}$concentrations in precipitation recovered during the latter period (2006-2009) to levels similar to those during the late 1980s and early 1990s (Fig. 2d). In contrast, $\mathrm{NO}_{\mathrm{x}}$ emissions over the US and Canada decreased by only $1 \%$ between 1991 and 1996 (Fig. 3). Comparable decreases in particulate $\mathrm{NO}_{3}^{-}$between 1991 and 1996 were not evident (Fig. 2c). The annual average $\mathrm{NO}_{3}^{-}$concentrations associated with aerosols under the NEUS/SEUS regime were generally higher than those for other regimes whereas VWA concentrations for precipitation overlapped to a greater degree (Fig. 2c, d). Presumably these relatively higher concentrations reflect contributions from reaction products of pollutant $\mathrm{NO}_{\mathrm{x}}$ emitted over eastern North America. However, temporal trends in $\mathrm{NO}_{3}^{-}$associated with both near-surface aerosols and precipitation under NEUS/SEUS flow appear to be largely decoupled from those of upwind $\mathrm{NO}_{\mathrm{x}}$ emissions in the US. In addition, temporal variability in particulate $\mathrm{NO}_{3}^{-}$in nearsurface aerosols was distinct from that for $\mathrm{VWA} \mathrm{NO}_{3}^{-}$in precipitation. We speculate that the efficient oxidation of $\mathrm{NO}_{\mathrm{x}}$ to $\mathrm{HNO}_{3}$ in marine air coupled with the subsequent partitioning of most $\mathrm{HNO}_{3}$ with large, short-lived marine aerosol (e.g., Russell et al., 2003; Fischer et al., 2006; Keene et al., 2009) tended to attenuate temporal variability in near-surface particulate $\mathrm{NO}_{3}^{-}$under a given flow regime relative to both upwind emissions of precursor $\mathrm{NO}_{\mathrm{x}}$ and particulate species such as nss $\mathrm{SO}_{4}^{2-}$ and $\mathrm{NH}_{4}^{+}$that are associated primarily with longer-lived submicrometer aerosol in marine air. The decreasing concentrations of primary marine aerosol with altitude and corresponding influences on $\mathrm{HNO}_{3}$ phase partitioning may have also contributed to divergence in the temporal variability in near-surface particulate $\mathrm{NO}_{3}^{-}$relative to $\mathrm{NO}_{3}^{-}$ scavenged from the column by precipitation. However, corresponding trends in mean particulate $\mathrm{Na}^{+}$and $\mathrm{VWA} \mathrm{Na}{ }^{+}$in precipitation at Bermuda (not shown) over the study period were not significant, which implies that interannual variability in production of marine aerosol did not directly influence trends in $\mathrm{NO}_{3}^{-}$. It is unclear why temporal trends in $\mathrm{HNO}_{3}$ and particulate $\mathrm{NO}_{3}^{-}$scavenged from the column by precipitation under NEUS/SEUS flow did not vary in response to corresponding decreases in emissions of precursor $\mathrm{NO}_{\mathrm{x}}$ over the upwind source region.

VWA $\mathrm{NO}_{3}^{-}$in precipitation associated with flow from the North increased significantly over the period of record (Fig. 2d; Table 2). All other trends in $\mathrm{NO}_{3}^{-}$concentrations for both aerosols and precipitation were insignificant at $p$ of 0.05 .

\subsection{3 $\mathrm{NH}_{4}^{+}$}

Temporal trends in $\mathrm{NH}_{4}^{+}$associated with both aerosols and precipitation under NEUS/SEUS flow were similar to those for $\mathrm{NO}_{3}^{-}$; none were significant (Fig. 2e, f; Table 2). The lack of significant trends in $\mathrm{NH}_{4}^{+}$concentrations is consistent with expectations based on trends in reported $\mathrm{NH}_{3}$ emissions over the US and Canada, which increased by only $1 \%$ between 1990 and 2009 (Fig. 3). The reported decrease in $\mathrm{NH}_{3}$ emissions in the US between 2000 and 2001 is an artifact associated with a change in the method used to estimate emissions (R. L. Dennis, US EPA, personal communication, 2014). Like both nss $\mathrm{SO}_{4}^{2-}$ and $\mathrm{NO}_{3}^{-}$, VWA $\mathrm{NH}_{4}^{+}$concentrations in precipitation decreased significantly during the early period of record (1991-1996) (SLR slope $=-0.19 \mu \mathrm{mol} \mathrm{L}^{-1} \mathrm{yr}^{-1}$, $\left.r^{2}=0.40\right)$ and then recovered (Fig. 2f). In contrast, between 1991 and 1996, reported $\mathrm{NH}_{3}$ emissions in the US and Canada increased by $9 \%$ (Fig. 3 ).

Like nss $\mathrm{SO}_{4}^{2-}$, particulate $\mathrm{NH}_{4}^{+}$associated with the Africa regime decreased significantly over the study period. In contrast, VWA $\mathrm{NH}_{4}^{+}$in precipitation sampled under Africa flow increased significantly (Fig. 2e, f; Table 2). As discussed in more detail below, these opposite trends may be driven in part by decreases in the acidity of the multiphase system and associate shifts in gas-aerosol phase partition of $\mathrm{NH}_{3}$. All other trends in $\mathrm{NH}_{4}^{+}$were insignificant. 


\subsection{Implications}

It is evident from the above that, in many cases, interannual variability and long-term trends in mean nss $\mathrm{SO}_{4}^{2-}, \mathrm{NO}_{3}^{-}$, and $\mathrm{NH}_{4}^{+}$in near-surface aerosol associated with the major flow regimes that transport air to Bermuda do not mirror corresponding patterns in $\mathrm{VWA} \mathrm{SO}_{4}^{2-}, \mathrm{NO}_{3}^{-}$, and $\mathrm{NH}_{4}^{+}$ in precipitation (Fig. 2). Precipitation scavenges both soluble gases and particles from the column whereas the measured aerosol composition reflects near-surface conditions. In addition, relative to the column, near-surface air is chemically processed to a greater degree via transformations involving freshly produced, large, and short-lived marine aerosol; direct interactions with the ocean surface via the dry deposition of both precursor gases and particles; and, emissions of $\left(\mathrm{CH}_{3}\right)_{2} \mathrm{~S}$ and, under clean conditions, $\mathrm{NH}_{3}$ (e.g., Bouwman et al., 1997) from the ocean surface. These near-surface processes contribute to differential variability in the composition of near-surface aerosols and precipitation reported herein. These results imply that, relative to near-surface aerosols, the composition of precipitation may be a better indicator of column-integrated trends in soluble atmospheric constituents. We also note that aerosol sampling was sector controlled whereas precipitation sampling was not. However, available evidence suggests that local emissions have minor to negligible influences on the composition of wet-only precipitation at Bermuda (Galloway et al., 1988, 1989, 1993).

Trends in aerosol and precipitation composition associated with the NEUS/SEUS flow regime did not track corresponding trends in emissions over the US and Canada during the entire study period. Indeed, the significant and roughly similar proportionate decreases in VWA nss $\mathrm{SO}_{4}^{2-}$ (factor of 2.2), $\mathrm{NO}_{3}^{-}$(factor of 1.9), and $\mathrm{NH}_{4}^{+}$(factor of 1.8) in precipitation associated with NEUS/SEUS flow between 1991 and 1996 (Fig. 2b, d, f) occurred in conjunction with reductions in $\mathrm{SO}_{2}$ and $\mathrm{NO}_{\mathrm{x}}$ emissions over the US and Canada of only $17 \%$ and $1 \%$, respectively, and an increase on $\mathrm{NH}_{3}$ emissions of $9 \%$ (Fig. 3). Corresponding patterns of decreasing particulate phase concentrations were not evident (Fig. 2a, c, e). These results imply that physical processes such as trends in the efficiency of upwind removal via wet and dry deposition as opposed to trends in upwind emissions drove the similar variability evident in the VWA concentrations of these species during this period. In this regard, we note that variability in mean precipitation amount per sample (Table 1) did not correlate with variability in VWA precipitation composition, which indicates that variable dilution associated with storm size (e.g., Galloway et al., 1989) was not a major factor driving interannual variability or trends in precipitation composition.

In contrast to the differences in concentrations associated with NEUS/SEUS flow and emissions in the US and Canada evident in our data, between 1980 and 2010, wet-deposition fluxes of $\mathrm{SO}_{4}^{2-}$ via precipitation and particulate $\mathrm{SO}_{4}^{2-}$ con- centrations in near-surface air over the eastern US decreased by $58 \%$ and $40 \%$, respectively and the corresponding $\mathrm{SO}_{2}$ emissions over the US decreased by $56 \%$ (Leibensperger et al. 2012). Between 1980 and 2009, wet deposition fluxes of $\mathrm{NO}_{3}^{-}$over the eastern US decreased $33 \%$ while corresponding $\mathrm{NO}_{\mathrm{x}}$ emissions decreased $36 \%$. Particulate $\mathrm{NO}_{3}^{-}$concentrations over the eastern US were relatively uniform from 1990 to 2000 but decreased by $23 \%$ between 2000 and 2009 (Leibensperger et al., 2012). Wet deposition fluxes of $\mathrm{NH}_{4}^{+}$ over the eastern US during this period exhibited no significant trend whereas the corresponding particulate $\mathrm{NH}_{4}^{+}$concentrations decrease by $30 \%$. Comparisons with measurements suggest that model calculations of these trends significantly underestimate the decreases in particulate $\mathrm{NO}_{3}^{-}$and $\mathrm{NH}_{4}^{+}$over this period (Leibensperger et al., 2012). Measured and simulated trends over the downwind western NAO were not reported.

It is evident from the above that temporal variability in (1) spatial distributions of emission fields over the NEUS/SEUS source region during the period of record, (2) the spatial distribution of transport within the NEUS/SEUS flow regime, and/or (3) spatial distributions of deposition fields under NEUS/SEUS flow contributed to temporal variability in aerosol and precipitation composition at Bermuda. However, available information, and particularly the lack of spatially resolved measurements of aerosol and precipitation composition over the western NAO precludes quantitative evaluation of these factors. Our results highlight the difficulty in characterizing influences of emission reductions based on measurements at individual sites located downwind.

Despite these limitations, results do provide unique insight regarding long-term trends in regional atmospheric composition. For example, although only the trend in particulate $\mathrm{NO}_{3}^{-}$was marginally significant, all trends in $\mathrm{NO}_{3}^{-}$and $\mathrm{NH}_{4}^{+}$ associated with aerosols and precipitation sampled under Oceanic flow over the period of record were positive and within a factor of about 2 in magnitude (31-67\%; Fig. 2c, $\mathrm{d}, \mathrm{e}, \mathrm{f})$. The consistency of these patterns suggests that background concentrations of inorganic $\mathrm{N}$ species in aged marine air within the NAO basin may have increased over the past 2 decades. In contrast, the corresponding concentrations of VWA nss $\mathrm{SO}_{4}^{2-}$ in precipitation associated with Oceanic flow decreased significantly (Fig. 2b; Table 2).

The changing mixture of acids and bases in the NAO troposphere impacts $\mathrm{pH}$-dependent chemical processes including the phase partitioning and associated atmospheric lifetimes against deposition for compounds with $\mathrm{pH}$-dependent solubilities. For example, trends of both aerosols and precipitation based on all data (Fig. 1; Table 2) and the subset of data associated with NEUS/SEUS flow (Fig. 2; Table 2) suggest that, on average, concentrations of nss $\mathrm{SO}_{4}^{2-}$ decreased, $\mathrm{NH}_{4}^{+}$remained essentially unchanged or increased, and $\mathrm{NO}_{3}^{-}$ remained essentially unchanged over the period of record. As discussed in Sect. 2.3, negative bias in particulate $\mathrm{NH}_{4}^{+}$ 

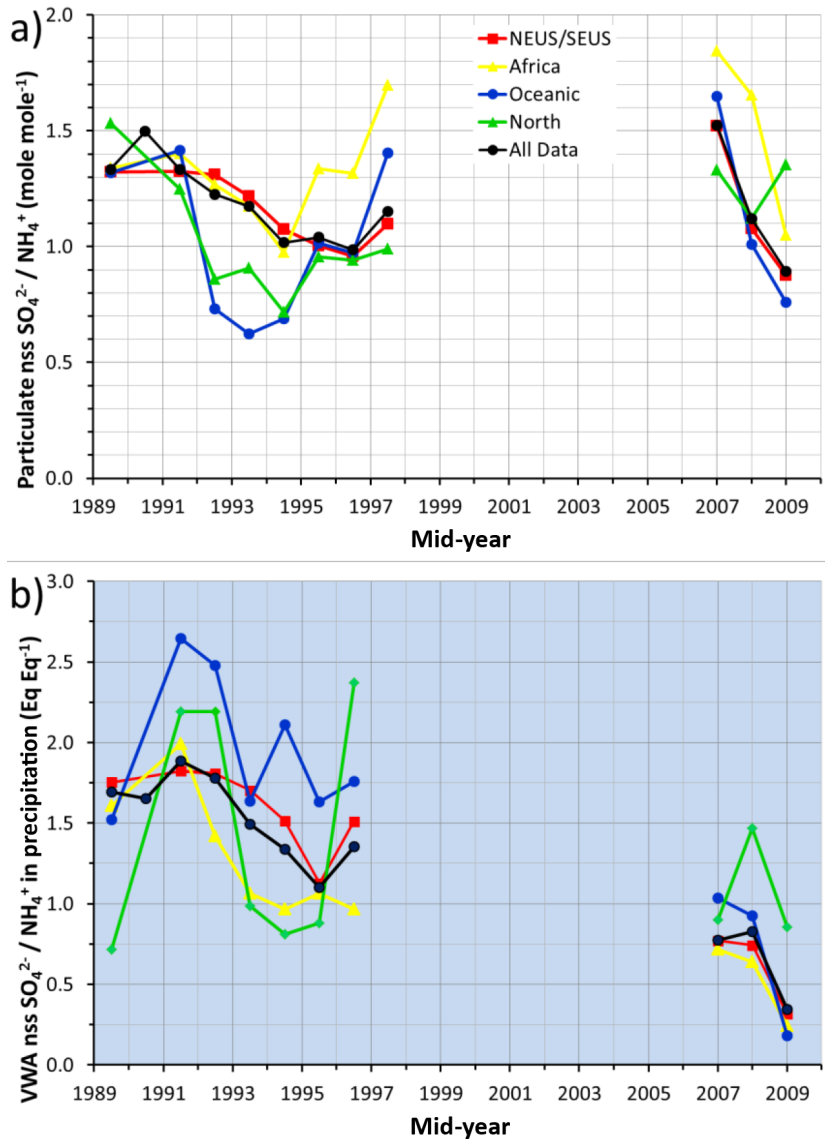

Figure 5. Temporal trends in (a) ratios of annual mean concentrations of particulate nss $\mathrm{SO}_{4}^{2-}$ versus $\mathrm{NH}_{4}^{+}$(white backgrounds) and (b) corresponding ratios of annual VWA concentrations in precipitation (light-blue backgrounds) associated with NEUS/SEUS (red), African (yellow), Oceanic (blue), and North (green) flow regimes and for all data (black).

resulting from artifact volatilization of $\mathrm{NH}_{3}$ from aerosol sampled in bulk during the early part of the record may have contributed to the positive trend in particulate $\mathrm{NH}_{4}^{+}$ but the positive trend for precipitation is not subject to such artifacts. These data imply that, on average, acidities of submicrometer-diameter aerosol solutions, with which most particulate $\mathrm{nss}^{2-} \mathrm{SO}_{4}^{2-}$ and $\mathrm{NH}_{4}^{+}$at Bermuda was associated (Moody et al., 2014), decreased over the period, particularly during the earlier part of the record. Decreasing aerosol acidities would have shifted the phase partitioning of total $\mathrm{NH}_{3}\left(\mathrm{NH}_{3}+\mathrm{NH}_{4}^{+}\right)$towards the gas phase (e.g., Smith et al., 2007) as is evident in the changing molar ratios of nss $\mathrm{SO}_{4}^{2-}$ to $\mathrm{NH}_{4}^{+}$over the period (Fig. 5). For example, based on the trend lines (Fig. 2; Table 2), between 1989 and 2009, ratios of mean nss $\mathrm{SO}_{4}^{2-}$ to $\mathrm{NH}_{4}^{+}$in near-surface aerosols associated with NEUS/SEUS flow decreased from 1.2 to 1.1 (factor of 1.1) whereas the corresponding ratios for VWA concentrations in precipitation decreased from 2.0 to 0.48 (factor of 4.3). The greater decrease in ratios for precipita- tion suggests that relative contributions to $\mathrm{NH}_{4}^{+}$in precipitation from the scavenging of gaseous $\mathrm{NH}_{3}$ versus particulate $\mathrm{NH}_{4}^{+}$increased over the period. This increase in relative contributions from $\mathrm{NH}_{3}$ would be consistent with expectations based on a $\mathrm{pH}$-dependent shift in the phase partitioning of total $\mathrm{NH}_{3}$ towards the gas phase coupled with efficient scavenging of both $\mathrm{NH}_{3}$ and particulate $\mathrm{NH}_{4}^{+}$by precipitation. In addition, because dry deposition velocities to the ocean surface for $\mathrm{NH}_{3}$ are greater than those for submicrometer aerosol size fractions with which most $\mathrm{NH}_{4}^{+}$is associated in ambient air (Smith et al., 2007; Moody et al., 2014), this shift would have resulted in an increase in the average dry-deposition flux of total $\mathrm{NH}_{3}$ to the ocean surface, a corresponding decrease in the fraction of total $\mathrm{NH}_{3}$ removed via wet deposition, and a decrease in the atmospheric lifetime of total $\mathrm{NH}_{3}$ against wet plus dry deposition. The long-term change in atmospheric acidity is also evident in the significant decrease (37\%) in VWA $\mathrm{H}^{+}$associated with precipitation sampled under NEUS/SEUS flow over the period of record (SLR slope $=-0.29 \mu \mathrm{mol} \mathrm{L}^{-1} \mathrm{yr}^{-1}, r^{2}=0.49$; Fig. 6). We recognize that trends reported herein are associated with large uncertainties, the corresponding changes in phase partition and deposition are nonlinear, and explicit evaluation of trends in aerosol solution $\mathrm{pH}$ and associated implications is not possible without paired measurements of particulate and gas phase species. However, these relationships provide a relevant quantitative context for aspects of $\mathrm{S}$ and $\mathrm{N}$ cycling over the North Atlantic that are driven by changing emissions over surrounding continents.

Despite the larger interannual variability evident in the temporal trends, our measurements and associated interpretations suggest that concentrations and deposition fluxes of total $\mathrm{NH}_{3}$ over the western $\mathrm{NAO}$ increased during the period of record. However, EPA (2013) and Environment Canada (2014) indicate that $\mathrm{NH}_{3}$ emissions in the US and Canada did not vary significantly between 1990 and 2009. If regionally representative, our results suggest the possibility that these inventories may underestimate increasing trends in $\mathrm{NH}_{3}$ emissions over North America. Alternatively, increasing transport of $\mathrm{NH}_{3}$ and particulate $\mathrm{NH}_{4}^{+}$from more distant sources in Asia may have contributed to rising atmospheric concentrations over the NAO. In this regard, Moody et al. (2014) detected significant mineral aerosol associated with NEUS flow that available evidence suggests originated in Asia. Other studies have reported that the transport of emission products from Asia significantly impact air quality over the western US although corresponding impacts in the eastern US are relatively small to negligible (e.g., Koch et al., 2007; Lin et al., 2014).

Because $\mathrm{HNO}_{3}$ partitions primarily with less-acidic supermicrometer-diameter aerosols, its cycling in marine air is largely decoupled from that of $\mathrm{NH}_{3}$. In addition, most acidity added to larger aerosol size fractions via accumulation of $\mathrm{HNO}_{3}$ and $\mathrm{H}_{2} \mathrm{SO}_{4}$ is displaced to the gas phase in association with $\mathrm{HCl}$ volatilization, which acts to regulate the 


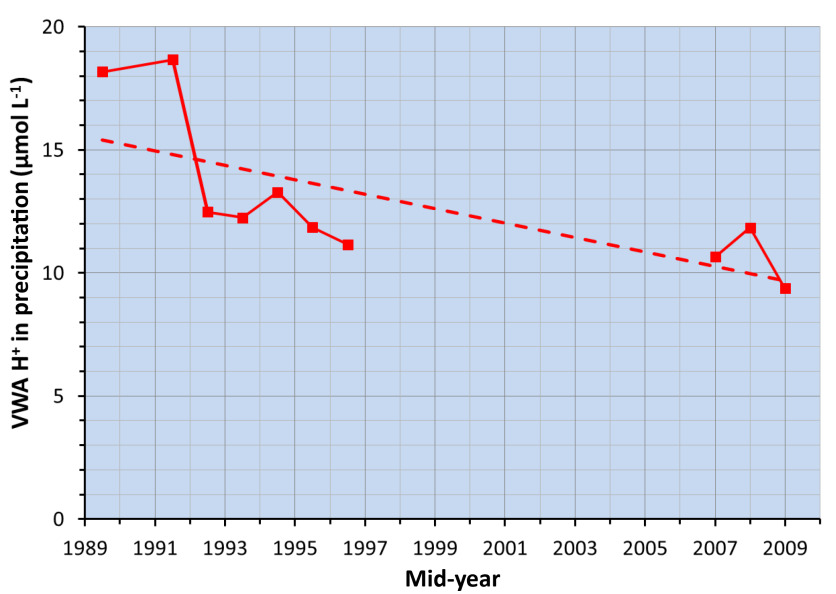

Figure 6. Temporal trend in annual VWA $\mathrm{H}^{+}$in precipitation associated with NEUS/SEUS flow.

$\mathrm{pH}$ of supermicrometer marine aerosols to a fairly narrow range (from low $3 \mathrm{~s}$ to high $4 \mathrm{~s}$ ) over highly variable chemical regimes (e.g., Keene et al., 2009). Consequently, relative to $\mathrm{NH}_{3}, \mathrm{HNO}_{3}$ cycling over the ocean is less sensitive to changes in atmospheric acidity. Similarly, particulate $\mathrm{NO}_{3}^{-}$ is also less sensitive than $\mathrm{NH}_{4}^{+}$to artifact volatilization from marine aerosol sampled in bulk.

Our results also provide insight regarding the potential influence of reductions in $\mathrm{SO}_{2}$ emissions from North America on direct radiative forcing by pollutant aerosols over the western NAO at Bermuda. Assuming that the marginally insignificant trend in particulate nss $\mathrm{SO}_{4}^{2-}$ associated with NEUS/SEUS flow is reasonably representative of the actual long-term decline, the SLR indicates that between 1989 and 2009 , annual average concentrations for this flow regime decreased by roughly $2.4 \mathrm{nmol} \mathrm{m}^{-3}$ or about $10 \%$ (Fig. 2a; Table 2). A regression fit to the scatter plot of satellite AOD at $550 \mathrm{~nm}$ versus $\mathrm{nss} \mathrm{SO}_{4}^{2-}$ associated with near-surface aerosol under NEUS flow regime during the period 20062009 reported by Moody et al. (2014) yields a slope of $0.002 \mathrm{nmol}^{-1} \mathrm{~m}^{3}$. Assuming that trends in other aerosol constituents that scatter and/or absorb radiation under this flow regime co-varied with particulate $\mathrm{nss}^{2-} \mathrm{SO}_{4}^{2-}$, the corresponding decrease in AOD (0.005) coupled with satellite-derived estimates for the radiative efficiency of aerosols per unit AOD in North American outflow over the ocean ( -27 to $-60 \mathrm{~W} \mathrm{~m}^{-2} \delta^{-1}$ ) (Anderson et al., 2005) yield an estimated net warming of $0.1-0.3 \mathrm{~W} \mathrm{~m}^{-2}$ that resulted from the de-

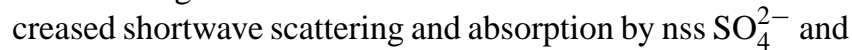
associated aerosol constituents under NEUS/SEUS flow at Bermuda between 1989 and 2009. As discussed above, the greater decreasing trend for $\mathrm{nss}^{\mathrm{SO}_{4}^{2-}}$ in precipitation relative to near-surface aerosols suggests that the decline in particulate nss $\mathrm{SO}_{4}^{2-}$ in near surface air was less than that for oxidized $\mathrm{S}$ in the column scavenged by precipitation. Consequently, this estimated range in warming should be con- sidered a lower limit. We appreciate that this approach is associated with large and poorly constrained uncertainties but it is reasonably consistent with expectations based on model estimates of the trend in net radiative warming of $0.8 \mathrm{~W} \mathrm{~m}^{-2}$ over the US resulting from the reduction in scattering and absorption by pollutant aerosols between 1990 and 2010 (Leibensperger et al., 2012).

\section{Summary}

Since the 1980s, mandated reductions in $\mathrm{SO}_{2}$ and $\mathrm{NO}_{\mathrm{x}}$ emissions in the US, Canada, and Europe have resulted in decreased export of oxidized $\mathrm{S}$ and $\mathrm{N}$ compounds to the NAO atmosphere. Measurements at Bermuda between 1989 and 2009 indicate that $\mathrm{nss}^{2-}$ associated with aerosols and precipitation decreased significantly ( $22 \%$ and $49 \%$, respectively) whereas $\mathrm{NH}_{4}^{+}$associated with precipitation increased significantly $(70 \%)$ (Fig. 1; Table 2). Corresponding trends in $\mathrm{NO}_{3}^{-}$associated with aerosols and precipitation and of particulate $\mathrm{NH}_{4}^{+}$were insignificant.

To assess influences of emissions in upwind regions, data were stratified based on FLEXPART retroplumes into four

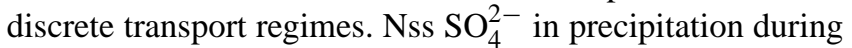
NEUS/SEUS and Oceanic flow decreased significantly $(61 \%$ each) whereas corresponding trends in $\mathrm{nss}^{\mathrm{SO}_{4}^{2-}}$ associated with near-surface aerosols for both flow regimes were insignificant (Fig. 2a, b; Table 2). Available evidence supports the hypothesis that, for these flow regimes, ratios of anthropogenic to biogenic contributions to $\mathrm{nss}^{2-} \mathrm{SO}_{4}^{2-}$ in the column scavenged by precipitation were relatively greater than those for near-surface aerosol and, thus, precipitation provided a better indicator of column-integrated trends.

Particulate $\mathrm{nss} \mathrm{SO}_{4}^{2-}$ under African flow also decreased significantly $(34 \%)$ whereas the corresponding decrease in nss $\mathrm{SO}_{4}^{2-}$ associated with precipitation was insignificant (Fig. 2a, b; Table 2). We infer that these trends were driven in part by reductions in the emissions and transport of oxidized $\mathrm{S}$ compounds from Europe.

Insignificant trends in $\mathrm{NO}_{3}^{-}$associated with aerosols and precipitation under NEUS/SEUS flow (Fig. 2c, d; Table 2) did not reflect the large decrease in $\mathrm{NO}_{\mathrm{x}}$ emissions in the US and Canada over the period of record (Fig. 3). The rapid oxidation of $\mathrm{NO}_{\mathrm{x}}$ in marine air coupled with partitioning of most $\mathrm{HNO}_{3}$ with large, short-lived marine aerosol may have attenuated trends in $\mathrm{NO}_{3}^{-}$concentrations relative to upwind $\mathrm{NO}_{\mathrm{x}}$ emissions.

Trends of both aerosols and precipitation based on all data (Fig. 1) and the subset of data associated with NEUS/SEUS flow (Fig. 2) suggest that, on average, concentrations of nss $\mathrm{SO}_{4}^{2-}$ decreased, $\mathrm{NH}_{4}^{+}$remained essentially unchanged or increased, and $\mathrm{NO}_{3}^{-}$remained essentially unchanged, which implies that the total amount of acidity in the multiphase gasaerosol system in the western NAO troposphere decreased over the period of record. This interpretation is consistent 
with the decreasing trend in VWA $\mathrm{H}^{+}$in precipitation under NEUS/SEUS flow (Fig. 6). The inferred decrease in aerosol acidities would have (1) shifted the phase partitioning of total $\mathrm{NH}_{3}$ towards the gas phase, (2) increased the dry deposition velocities for total $\mathrm{NH}_{3}$ to the ocean surface, (3) increased relative contributions to $\mathrm{NH}_{4}^{+}$in precipitation from the scavenging of gaseous $\mathrm{NH}_{3}$ versus particulate $\mathrm{NH}_{4}^{+}$, and (4) decreased the atmospheric lifetime of total $\mathrm{NH}_{3}$ against wet plus dry deposition.

Assuming that the marginally insignificant trend in particulate $\mathrm{nsS} \mathrm{SO}_{4}^{2-}$ in near-surface air associated with NEUS/SEUS flow is reasonably representative of long-term temporal variability (Fig. 2a; Table 2), decreasing concentrations over the period of record suggest a lower limit for net warming in the range of $0.1-0.3 \mathrm{~W} \mathrm{~m}^{-2}$ resulting from

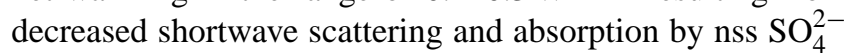
and associated aerosol constituents transported from North America over the western NAO.

Acknowledgements. Dennis Savoie, Hal Maring, Kenneth Voss, and Miguel Izaguirre collaborated in conceptualizing and conducting these research efforts. Annie Glasspool, Kim Zeeh and Chris Marsay assisted in field operations and data generation and processing. Peter Sedwick and Andrew Peters supervised operations at the THAO during the latter period of record and the Bermuda Institute for Ocean Sciences provided outstanding logistical support during both measurement periods. ECMWF provided meteorological data used to calculate FLEXPART retroplumes. Funding was provided by the National Science Foundation through awards to the University of Virginia (AGS-8701291, -9013128, -9414293, and -0541570) and the University of Miami (AGS-8703411, -9013062, -9414262, and -0541566).

Edited by: M. C. Facchini

\section{References}

Anderson, T. L., Charlson, R. J., Bellouin, N., Boucher, O., Chin, M., Christopher, S. A., Haywoo, J., Kaufman, Y. J., Kinne, S., Ogren, J. A., Remer, L. A., Takemura, T., Tanre, D., Torres, O., Trepte, C. R., Wielicki, B. A., Winker, D. M., and Yu, H.: An "A-Train" strategy for quantifying direct climate forcing by anthropogenic aerosols, B. Am. Meteorol. Soc., 12, 17951809, 2005.

Arimoto, R., Duce, R. A., Ray, B. J., Ellis Jr., W. G., Cullen, J. D., and Merrill, J. T.: Trace elements in the atmosphere over the North Atlantic, J. Geophys. Res., 100, 1199-1213, 1995.

Arimoto, R., Snow, J. A., Graustein, W. C., Moody, J. L., Ray, B. J., Duce, R. A., Turekian, K. K., and Maring, H. B.: Influences of atmospheric transport pathways on radionuclide activities in aerosol particles from over the North Atlantic, J. Geophys. Res., 104, 21301-21316, 1999.

Bouwman, A. F., Lee, D. S., Asman, W. A. H., Dentener, F. J., Van Der Hock, K. W., and Olivier, J. G. J.: A global high-resolution emission inventory for ammonia, Global Biogeochem. Cy., 11, 561-587, 1997.

Chen, L. and Duce, R. A.: The sources of sulfate, vanadiaum, and mineral matter in aerosol particles over Bermuda, Atmos. Environ., 17, 2055-2064, 1983.

Darwin, C.: An account of this fine dust that often falls on vessels in the Atlantic Ocean, The Quarterly journal of the Geological Society of London, 2, 26-30, 1846.

Dobson, M.: An account of the Harmattan, a singular African wind, Philosophical Transactions of the Royal Society of London, 71, 46-57, 1781.

Environment Canada: Air Pollutant Emissions Data, http://www.ec. gc.ca/inrp-npri/donnees-data/ap/index.cfm (last access: 22 May 2014), 2014.

EPA, National Emissions Inventory (NEI) Air Pollutant Emissions Trends Data, Office of Air Quality Planning and Standards, Technology Transfer Network, Clearing House for Inventories \& Emissions Factors, available at: http://www.epa.gov/ttn/chief/ trends/ (last access: 16 February 2014), 2013.

Evan, A. T., Heidinger, A, K., and Knippertz, P.: Analysis of winter dust activity off the coast of West Africa using a new 24 year over-water advanced very high resolution radiometer satellite dust climatology, J. Geophys. Res., 111, D12210, doi:10.1029/2005JD006336, 2006.

Freedman, D. A.: Bootstrapping regression models, Ann. Stat., 9, 1218-1228, 1981.

Fischer, E., Pszenny, A. Keene, W., Maben, J., Smith, A., Stohl, A., and Talbot, R.: Nitric acid phase partitioning and cycling in the New England coastal atmosphere, J. Geophys. Res., 111, D23S09, doi:10.1029/2006JD007328, 2006.

Galloway, J. N., Tokos, Jr., J. J., Knap, A. H., and Keene, W. C.: Local influences on the composition of precipitation on Bermuda, Tellus B, 40, 178-188, 1988.

Galloway, J. N., Keene, W. C., Artz, R. S., Church, T. M., and Knap, S. H.: Processes controlling the concentrations of $\mathrm{SO}_{4}^{=}$, $\mathrm{NO}_{3}^{-}, \mathrm{NH}_{4}^{+}, \mathrm{H}^{+}, \mathrm{HCOO}_{\mathrm{T}}$ and $\mathrm{CH}_{3} \mathrm{COO}_{\mathrm{T}}$ in precipitation on Bermuda, Tellus B, 41, 427-443, 1989.

Galloway, J. N., Savoie, D. L., Keene, W. C., and Prospero, J. M.: The temporal and spatial variability of scavenging ratios for nss sulfate, nitrate, methanesulfonate and sodium in the atmosphere over the North Atlantic Ocean, Atmos. Environ., 27, 235-250, 1993.

Hand, J. L., Schichtel, B. A., Malm, W. C., and Pitchford, M. L.: Particulate sulfate ion concentration and $\mathrm{SO}_{2}$ emission trends in the United States from the early 1990s through 2010, Atmos. Chem. Phys., 12, 10353-10365, doi:10.5194/acp-1210353-2012, 2012.

Hastings, M. G., Sigman, D. M., and Lipschultz, F.: Isotopic evidence for source changes of nitrate in rain at Bermuda, J. Geophys. Res., 108, 4790, doi:10.1029/2003JD003789, 2003.

Herlihy, L. J., Galloway, J. N., and Mills, A. L.: Bacterial utilization of formic and acetic acid in rainwater, Atmos. Environ., 21, 2397-2402, 1987.

Hsu, N. C., Gautam, R., Sayer, A. M., Bettenhausen, C., Li, C., Jeong, M. J., Tsay, S.-C., and Holben, B. N.: Global and regional trends of aerosol optical depth over land and ocean using SeaWiFS measurements from 1997 to 2010, Atmos. Chem. Phys., 12, 8037-8053, doi:10.5194/acp-12-8037-2012, 2012. 
Jickells, T., Knap, A., Church, T., Galloway, J., and Miller, J.: Acid rain on Bermuda, Nature, 297, 55-57, 1982.

Kahl, J. S., Stoddard, J. L., Haeuber, R., Paulsen, S. G., Birnbaum, R., Deviney, F. A., Webb, J. R., DeWalle, D. R., Sharpe, W., Driscoll, C. T., Herlihy, A. T., Kellogg, J. H., Murdoch, P. S., Roy, K., Webster, K. E., and Urquhart, N. S.: Have US surface waters responded to the 1990 Clean Air Act Amendments?, Environ. Sci. Technol., 38, 484A-490A, 2004.

Keene, W. C., Galloway, J. N., and Holden, Jr., J. D.: Measurement of weak organic acidity in precipitation from remote areas of the world, J. Geophys. Res., 88, 5122-5130, 1983.

Keene, W. C., Pszenny, A. A. P., Galloway, J. N., and Hawley, M. E.: Sea-salt corrections and interpretation of constituent ratios in marine precipitation, J. Geophys. Res., 91, 6647-6658, 1986.

Keene, W. C., Talbot, R. W., Andreae, M. O., Beecher, K., Berresheim, H., Castro, M., Farmer, J. C., Galloway, J. N., Hoffman, M. R., Li, S.-M., Maben, J. R., Munger, J. W., Norton, R. B., Pszenny, A. A. P., Puxbaum, H., Westberg, H., and Winiwarter, W.: An intercomparison of measurement systems for vapor- and particulate-phase concentrations of formic and acetic acids, J. Geophys. Res., 94, 6457-6471, 1989.

Keene, W. C., Pszenny, A. A. P., Jacob, D. J., Duce, R. A., Galloway, J. N., Schultz-Tokos, J. J., Sievering, H., and Boatman, J. F.: The geochemical cycling of reactive chlorine through the marine troposphere, Global Biogeochem. Cy., 4, 407-430, 1990.

Keene, W. C., Sander, R., Pszenny, A. A. P., Vogt, R., Crutzen, P. J., and Galloway, J. N.: Aerosol pH in the marine boundary layer: a review and model evaluation, J. Aerosol Sci., 29, 339-356, 1998.

Keene, W. C., Pszenny, A. A. P., Maben, J. R., Stevenson, E., and Wall, A.: Closure evaluation of size-resolved aerosol $\mathrm{pH}$ in the New England coastal atmosphere during summer, J. Geophys. Res., 109, 307, doi:10.1029/2004JD004801, 2004.

Keene, W. C., Long, M. S., Pszenny, A. A. P., Sander, R., Maben, J. R., Wall, A. J., O'Halloran, T. L., Kerkweg, A., Fischer, E. V., and Schrems, O.: Latitudinal variation in the multiphase chemical processing of inorganic halogens and related species over the eastern North and South Atlantic Oceans, Atmos. Chem. Phys., 9, 7361-7385, doi:10.5194/acp-9-7361-2009, 2009.

Koch, D., Bond, T. C., Streets, D., Unger, N., and van der Werf, R. G.: Global impacts of aerosols from particular source regions and sectors, J. Geophys. Res., 112, D02205, doi:10.1029/2005JD007024, 2007.

Leibensperger, E. M., Mickley, L. J., Jacob, D. J., Chen, W.-T., Seinfeld, J. H., Nenes, A., Adams, P. J., Streets, D. G., Kumar, N., and Rind, D.: Climatic effects of 1950-2050 changes in US anthropogenic aerosols - Part 1: Aerosol trends and radiative forcing, Atmos. Chem. Phys., 12, 3333-3348, doi:10.5194/acp-12-33332012, 2012.

Lin, C. T., Baker, A. R., Jickells, T. D., Kelly, S., and Lesworth, T.: An assessment of the significance of sulphate sources over the Atlantic Ocean based on sulphur isotope data, Atmos. Environ., 62, 615-621, 2012.

Lin, J., Pan, D., Davis, S. J., Zhang, Q., He, K., Wang, C., Streets, D. G., Wuebbles, D. J., and Guan, D.: China's international trade and air pollution in the United States, P. Natl. Acad. Sci. USA, 21, 1-6, doi:10.1073/pnas.1312860111, 2014.
Liu, B. Y. H., Pui, D. Y. H., Wang, X. Q., and Lewis, C. W.: Sampling of carbon fiber aerosols, Aerosol Sci. Tech., 2, 499-511, 1983.

Mari, C., Jacob, D. J., and Bechtold, P.: Scavenging and transport of soluble gases in a deep convective cloud, J. Geophys. Res., 105, 22255-22267, 2000.

Millero, F. J. and Sohn, M. L.: Chemical Oceanography, CRC Press, Boca Raton, Fl., 531 pp., 1992.

Moody, J. L. and Galloway, J. N.: Quantifying the relationship between atmospheric transport and the chemical composition of precipitation on Bermuda, Tellus B, 40, 463-479, 1988.

Moody, J. L., Oltmans, S. J., Levy II, H., and Merrill, J. T.: Transport climatology of tropospheric ozone: Bermuda, 1988-1991, J. Geophys. Res., 100(D4), 7179-7194, 1995.

Moody, J. L., Keene, W. C., Cooper, O. R., Voss, K. J., Aryal, R., Eckhardt, S., Holben, B., Maben, J. R., Izaguirre, M. A., and Galloway, J. N.: Flow climatology for physicochemical properties of dichotomous aerosol over the western North Atlantic Ocean at Bermuda, Atmos. Chem. Phys., 14, 691-717, doi:10.5194/acp14-691-2014, 2014.

Neuman, J. A., Parrish, D. D., Trainer, M., Ryerson, T. B., Holloway, J. S., Nowak, J. B., Swanson, A., Flocke, F., Roberts, J. M., Brown, S. S., Stark, H., Sommariva, R., Stohl, A., Peltier, R., Weber, R., Wollny, A., Sueper, D. T., Hubler, G., and Fehsenfeld, F. C.: Reactive nitrogen transport and photochemistry in urban plumes over the North Atlantic Ocean, J. Geophys. Res., 111, D23S54, doi:10.1029/2005JD007010, 2006.

Prospero, J. M., Bullard, J. E., and Hodgkins, R.: High-latitude dust over the North Atlantic: inputs from Icelandic proglacial dust storms, Science, 335, 1078-1082, 2012.

Russell, K. M., Keene, W. C., Maben, J. R., Galloway, J. N., and Moody, J. L.: Phase-partitioning and dry deposition of atmospheric nitrogen at the mid-Atlantic US coast, J. Geophys. Res., 108, 4656, doi:10.1029/2003JD003736, 2003.

Savoie, D. L., Prospero, J. M., and Saltzman, E. S.: Non-sea-salt sulfate and nitrate in tradewind aerosols at Barbados: evidence for long-range transport, J. Geophys. Res., 94, 5069-5080, 1989.

Savoie, D. L., Arimoto, R., Keene, W. C., Prospero, J. M., Duce, R. A., and Galloway, J. N.: Marine biogenic and anthropogenic contributions to non-sea-salt sulfate in the marine boundary layer over the North Atlantic Ocean, J. Geophys. Res., 107, 4356, doi:10.1029/2001JD000970, 2002.

Seibert, P. and Frank, A.: Source-receptor matrix calculation with a Lagrangian particle dispersion model in backward mode, Atmos. Chem. Phys., 4, 51-63, doi:10.5194/acp-4-51-2004, 2004.

Smith, A. M., Keene, W. C., Maben, J. R., Pszenny, A. a. P., Fischer, E., and Stohl, A.: Ammonia sources, transport, transformation, and deposition in coastal New England during summer, J. Geophys. Res., 112, D10S08, doi:10.1029/2006JD007574, 2007.

Shen, G. T. and Boyle, E. A.: Lead in corals: reconstruction of historical industrial fluxes to the surface ocean, Earth Planet. Sc. Lett., 82, 289-304, 1987.

Stohl, A., Hittenberger, M., and Wotawa, G.: Validation of the Lagrangian particle dispersion model FLEXPART against large scale tracer experiment data, Atmos. Environ., 32, 4245-4264, 1998.

Stohl, A., Forster, C., Eckhardt, S., Spichtinger, N., Huntrieser, H., Heland, J., Schlager, H., Wilhelm, S., Arnold, F., and Cooper, O.: A backward modeling study of intercontinental pollution trans- 
port using aircraft measurements, J. Geophys. Res., 108, 4370, doi:10.1029/2002JD002862, 2003.

Stohl, A., Forster, C., Frank, A., Seibert, P., and Wotawa, G.: Technical note: The Lagrangian particle dispersion model FLEXPART version 6.2, Atmos. Chem. Phys., 5, 2461-2474, doi:10.5194/acp-5-2461-2005, 2005.

Streets, D. G., Yan, F., Chin, M., Diehl, T., Mahowald, N., Schultz, M., Wild, M., Wu, Y., and Yu, C.: Anthropogenic and natural contributions to regional trends in aerosol optical depth, 1980-2006, J. Geophys. Res., 114, D00-D18, doi:10.1029/2008JD011624, 2009.

Turekian, V. C., Macko, S. A., and Keene, W. C.: Application of stable sulfur isotopes to differentiate sources of size-resolved particulate sulfate in polluted marine air at Bermuda during spring, Geophys. Res. Lett., 28, 1491-1494, 2001.

Turekian, V. C., Macko, S. A., and Keene, W. C.: Concentrations, isotopic compositions, and sources of size-resolved, particulate organic carbon and oxalate in near-surface marine air at Bermuda during spring, J. Geophys. Res., 108, 4157, doi:10.1029/2002JD002053, 2003.

Vestreng, V., Myhre, G., Fagerli, H., Reis, S., and Tarrasón, L.: Twenty-five years of continuous sulphur dioxide emission reduction in Europe, Atmos. Chem. Phys., 7, 3663-3681, doi:10.5194/acp-7-3663-2007, 2007. von Glasow, R., Sander, R., Bott, A., and Crutzen, P. J.: Modeling halogen chemistry in the marine boundary layer, 2 . Interactions with sulfur and cloud-covered MBL, J. Geophys. Res., 107, 4323, doi:10.1029/2001JD000943, 2002.

Webb, J. R., Cosby, B. J., Deviney, Jr., F. A., Galloway, J. N., Maben, S. W., and Bulger, A. J.; Are brook trout streams in western Virginia and Shenandoah National Park recovering from acidification?, Environ. Sci. Technol., 38, 4091-4096, 2004.

Wilson, T. R. S.: Salinity and the major elements of sea water, in: Chemical Oceanography, vol. 1, 2nd edn., edited by: Riley, J. P. and Skirrow, G., 365-413, Academic Press, Orlando, FL, 1975.

Zhang, J. and Reid, J. S.: A decadal regional and global trend analysis of the aerosol optical depth using a data-assimilation grade over-water MODIS and Level 2 MISR aerosol products, Atmos. Chem. Phys., 10, 10949-10963, doi:10.5194/acp-1010949-2010, 2010.

Zhao, T. X. P., Laszlo, I., Guo, W., Heidinger, A., Cao, C., Jelenak, A., Tarpley, D., and Sullivan, J.: Study of long-term trend in aerosol optical thickness observed from operational AVHRR satellite instrument, J. Geophys. Res., 113, D07201, doi:10.1029/2007JD009061, 2008.

Zoller, W. H., Gordon, G. E., Gladney, E. S., and Jones, A. G.: The sources and distribution of vanadium in the atmosphere, in Trace Elements in the Environment, American Chemical Society, Washington, DC, Adv. Chem. Ser., 123, 31-47, 1973 